\title{
MAKING MAXIMUM USE OF TAX-DEFERRED RETIREMENT ACCOUNTS
}

\author{
Janette Kawachi, Karen E. Smith, and Eric J. Toder
}

CRR WP 2005-19

Released: December 2005

Draft Submitted: December 2005

\author{
Center for Retirement Research at Boston College \\ 550 Fulton Hall \\ 140 Commonwealth Ave. \\ Chestnut Hill, MA 02467 \\ Tel: 617-552-1762 Fax: 617-552-1750 \\ http://www.bc.edu/crr
}

\begin{abstract}
* Janette Kawachi is a Research Associate at the Urban Institute. Karen Smith is a Senior Research Associate at The Urban Institute. Dr. Toder supervises studies on Social Security, other retirement issues, and tax issues in the Income and Benefits Center and the Urban-Brookings Tax Policy Center at the Urban Insititute. The research reported herein was performed, in part, pursuant to a grant from the U.S. Social Security Administration (SSA) funded as part of the Retirement Research Consortium. The findings and conclusions expressed are solely those of the authors and do not represent the views of SSA, any agency of the Federal Government, or Boston College or the Urban Institute, members of its board, or its sponsors. The authors thank Richard Johnson and Sheila Zedlewski for comments on an earlier draft of this paper.
\end{abstract}

(C) 2005, by Janette Kawachi, Karen E. Smith, and Eric J. Toder. All rights reserved. Short sections of text, not to exceed two paragraphs, may be quoted without explicit permission provided that full credit, including $(\odot)$ notice, is given to the source. 


\section{About the Center for Retirement Research}

The Center for Retirement Research at Boston College, part of a consortium that includes a parallel centers at the University of Michigan and the National Bureau of Economic Research, was established in 1998 through a grant from the Social Security Administration. The goals of the Center are to promote research on retirement issues, to transmit new findings to the policy community and the public, to help train new scholars, and to broaden access to valuable data sources. Through these initiatives, the Center hopes to forge a strong link between the academic and policy communities around an issue of critical importance to the nation's future.

\section{Center for Retirement Research at Boston College \\ 550 Fulton Hall \\ 140 Commonwealth Ave. \\ Chestnut Hill, MA 02467 \\ phone: 617-552-1762 fax: 617-552-0191 \\ e-mail: crr@bc.edu \\ http://www.bc.edu/crr}

\section{Affiliated Institutions:}

American Enterprise Institute

The Brookings Institution

Center for Strategic and International Studies

Massachusetts Institute of Technology

Syracuse University

Urban Institute 


\begin{abstract}
The share of workers who participate in employer-sponsored tax-deferred plans has been growing, but is still only a minority of workers. Most workers do not contribute the maximum amount allowed by law to employer-sponsored plans. Maximum contributors are more prevalent among high-income compared with low-income workers, college graduates compared with those with less education, non-Hispanic whites and others compared with non-Hispanic blacks and Hispanics, and single and married people, compared with those who are widowed or divorced.
\end{abstract}

The percentage of participants who contribute the maximum to employersponsored plans almost doubled between 1990 and 2003, but virtually all the growth in maximum participation came from groups with high shares of maximum contributors in 1990. The share of participants who are large contributors - defined as contributing the maximum or 10 percent of their earnings to plans - also nearly doubled. For large contributors, the growth came from all income and demographic groups, although growth also increased the most (in percentage points) for groups with large shares in 1990.

Holding all other factors constant, we find an upward trend in the share of large contributors among high-earners, but not among low-earners. Shares of both maximum and large contributors are increasing more over time for higher than for lower earning groups. Recent increases in contribution limits can be expected to reduce shares of maximum contributors, but raise relative shares of maximum contributors among highearning and education groups. Increases in contribution limits do little to increase retirement preparedness among lower-income groups. 


\section{INTRODUCTION}

In the past quarter century, defined contribution plans have grown rapidly and are now replacing traditional defined benefit plans as the primary retirement savings instrument for most American workers. This change has shifted greater responsibility for retirement saving from employers to individuals. Future benefits from these accounts depend on the level of contributions from participants (and their employers) during their wage-earning years.

Under Section 401 (k) of the Internal Revenue Code, enacted in 1978, employer and employee contributions to tax-deferred retirement accounts are excluded from wages subject to the income tax, although employee contributions are included in the base for payroll taxes. ${ }^{1}$ Earnings within the accounts are tax-free, but withdrawals in the form of lump-sum payments or annuity payments are taxable. In the Economic Growth and Tax Relief Reconciliation Act of 2001, Congress raised the maximum allowable contributions to defined contribution plans and proposals for further increases will likely remain on the legislative agenda. The report of the President's Advisory Panel on Federal Tax Reform (2005) proposes no changes in maximum contributions to employer-sponsored plans, but greatly expands and simplifies provisions that allow individuals to deposit funds in tax-exempt individual saving plans.

Previous studies have shown that most employees contribute less than the legal maximum to employer-sponsored plans. This paper examines changes between 1990 and 2003 in the share of workers in different demographic groups who contribute the legal maximum. Using administrative data on employee contributions to employer-sponsored plans, combined with demographic data on individuals, we find that the percentage of employees who contribute the maximum allowed amounts to plans has increased between 1990 and 2003, but that this increase has been largest among those earnings and demographic groups with the highest shares of maximum contributors. We reach roughly similar conclusions about trends in shares of large contributors, defined as those who contribute either 10 percent of earnings or the maximum amount. The results in this paper reinforce earlier findings that increases in the maximum allowable contribution may have little effect on retirement security for most workers.

The first section of this paper describes the limitations on contributions to employersponsored plans and how they have evolved over time. We begin by describing how statutory contribution limits are set and how they have evolved over time. We then review recent literature on the factors that influence employee contributions to salary reduction plans and display summary data on the shares of employees who were offered and participated in employer-sponsored plans in 1992, 1996, and 2001. We then describe the data used in this paper and present data that show how shares of workers who contribute the statutory maximum to defined contribution plans have increased over time for different earnings and demographic groups. For the same groups, we also

\footnotetext{
${ }^{1}$ Similar provisions for tax-deferred accounts for employees of non-profit institutions are included in Section 403b of the Internal Revenue Code. We will refer to all the plans as tax-deferred retirement accounts. These include the following type plans: cash or deferred arrangements (section 401(k) plans); Thrift Savings Plan for federal employees; salary reduction simplified employee pension plans (SARSEP); savings incentive match plans for employees (SIMPLE plans); tax-sheltered annuity plans (403(b) plans); section 501(c)(18)(D) plans; and section 457 plans.
} 
display changes in the percentages of large contributors (as defined above). Finally, we estimate a number of logit models that explain the probability of contributing the statutory maximum and the probability of contributing at least 10 percent of annual earnings $o r$ the statutory maximum and how that probability has evolved over time. A brief concluding section reviews the findings.

\section{Background}

\section{Contribution Limits}

The federal income tax law limits contributions to tax-deferred defined contribution (DC) pension plans in three main ways: 1) an annual dollar limit on the amount an employee can contribute to a DC plan, 2) an annual dollar limit on the combined amount that an employer and an employee can contribute to an account, and 3) percentage-of-compensation limits on combined employer and employee contributions. Contributions to tax-deferred retirement plans are limited to the lowest of these three limits. Table 1a shows how these contribution limits have varied over time. This paper focuses on employee dollar contribution limits.

In tax year 2005 , employees may contribute up to $\$ 14,000$ to $401 \mathrm{k}$ plans. The contribution limit will be raised to $\$ 15,000$ in 2006 and will be indexed after 2006 to changes in the consumer price index. Employees ages 50 and over may make additional "catch-up" contributions to the accounts of $\$ 4,000$ in tax year 2005 and $\$ 5,000$ in tax year 2006, for a total contribution of $\$ 20,000$ in 2006. After 2006, the catch-up contribution limit is also indexed to changes in the consumer price index.

This paper examines changes in the shares of workers contributing the maximum allowable amount between 1990 and 2003. Over this period, the limit on individual contributions increased from $\$ 7,979$ in 1990 to $\$ 12,000$ in 2003. Additional "catch up" contributions for employees over age 50 were permitted beginning in 2002; the limits for these additional contributions were $\$ 1,000$ in 2002 and $\$ 2,000$ in 2003. Employers and employees were subject to a combined limit for contributions to defined contribution plans of $\$ 30,000$ between 1990 and 2000. The combined limit was raised to $\$ 35,000$ in 2001 and $\$ 40,000$ in 2002. Between 1990 and 2001, combined contributions were also limited to 25 percent of annual earnings (including contributions); this limit was raised to 100 percent in 2002.

While contribution limits were rising in nominal terms throughout the 1990-2001 period (Table 1b), their growth was slower than the growth in average wages for much of that period, declining from 38 percent of the average wage in 1990 to 32 percent of the average wage in 2001. Since 2001, contribution limits have risen sharply as a percentage of the average wage; by 2006, they will reach 39 percent of the average wage for employees under 50 and 52 percent of the average wage for employees over 50, including the effect of allowable "catch-up" contributions. 
Table 1a. 401k Plan Contribution Limits and Catch-up Provisions 1990 - 2003

\begin{tabular}{|l|c|c|c|c|}
\hline \multicolumn{3}{|c|}{ Dollar Limits } & Percent Limits \\
\hline Year & $\begin{array}{c}\text { Employee } \\
\text { Contributions }\end{array}$ & Over 50 Catch up & $\begin{array}{c}\text { Combined Employer- } \\
\text { Employee }\end{array}$ & $\begin{array}{c}\text { Percent of Annual } \\
\text { Salary }\end{array}$ \\
\hline $\mathbf{1 9 9 0}$ & $\$ 7,979$ & - & $\$ 30,000$ & $25 \%$ \\
$\mathbf{1 9 9 1}$ & $\$ 8,475$ & - & $\$ 30,000$ & $25 \%$ \\
$\mathbf{1 9 9 2}$ & $\$ 8,728$ & - & $\$ 30,000$ & $25 \%$ \\
$\mathbf{1 9 9 3}$ & $\$ 8,994$ & - & $\$ 30,000$ & $25 \%$ \\
$\mathbf{1 9 9 4}$ & $\$ 9,240$ & - & $\$ 30,000$ & $25 \%$ \\
$\mathbf{1 9 9 5}$ & $\$ 9,240$ & - & $\$ 30,000$ & $25 \%$ \\
$\mathbf{1 9 9 6}$ & $\$ 9,500$ & - & $\$ 30,000$ & $25 \%$ \\
$\mathbf{1 9 9 7}$ & $\$ 9,500$ & - & $\$ 30,000$ & $25 \%$ \\
$\mathbf{1 9 9 8}$ & $\$ 10,000$ & - & $\$ 30,000$ & $25 \%$ \\
$\mathbf{1 9 9 9}$ & $\$ 10,000$ & - & $\$ 30,000$ & $25 \%$ \\
$\mathbf{2 0 0 0}$ & $\$ 10,500$ & - & $\$ 30,000$ & $25 \%$ \\
$\mathbf{2 0 0 1}$ & $\$ 10,500$ & - & $\$ 35,000$ & $25 \%$ \\
$\mathbf{2 0 0 2}$ & $\$ 11,000$ & 1,000 & $\$ 40,000$ & $100 \%$ \\
$\mathbf{2 0 0 3}$ & $\$ 12,000$ & 2,000 & $\$ 40,000$ & $100 \%$ \\
$\mathbf{2 0 0 4}$ & $\$ 13,000$ & $\$ 3,000$ & $\$ 41,000$ & $100 \%$ \\
$\mathbf{2 0 0 5}$ & $\$ 14,000$ & $\$ 4,000$ & $\$ 42,000$ & $100 \%$ \\
$\mathbf{2 0 0 6}$ & $\$ 15,000$ & $\$ 5,000$ & $\$ 44,000$ & $100 \%$ \\
\hline
\end{tabular}

Source: Internal Revenue Code, various years.

Table 1b. Employee Contribution Limits as a Percent of National Average Wage $1990-2003$

\begin{tabular}{|c|c|c|c|c|c|}
\hline & & \multicolumn{2}{|c|}{ Dollar Limits } & \multicolumn{2}{|c|}{ As a Percent of Average Wage } \\
\hline Year & $\begin{array}{c}\text { National Average } \\
\text { Wage }\end{array}$ & $\begin{array}{c}\text { Employee } \\
\text { Contributions } \\
\text { without Over } 50 \\
\text { Catch up } \\
\end{array}$ & $\begin{array}{c}\text { Employee } \\
\text { Contributions with } \\
\text { Over } 50 \text { Catch up }\end{array}$ & $\begin{array}{c}\text { Employee } \\
\text { Contributions } \\
\text { without Over } 50 \\
\text { Catch up } \\
\end{array}$ & $\begin{array}{c}\text { Employee } \\
\text { Contributions with } \\
\text { Over } 50 \text { Catch up }\end{array}$ \\
\hline 1990 & $\$ 21,027.98$ & $\$ 7,979$ & $\$ 7,979$ & $37.9 \%$ & $37.9 \%$ \\
\hline 1991 & $\$ 21,811.60$ & $\$ 8,475$ & $\$ 8,475$ & $38.9 \%$ & $38.9 \%$ \\
\hline 1992 & $\$ 22,935.42$ & $\$ 8,728$ & $\$ 8,728$ & $38.1 \%$ & $38.1 \%$ \\
\hline 1993 & $\$ 23,132.67$ & $\$ 8,994$ & $\$ 8,994$ & $38.9 \%$ & $38.9 \%$ \\
\hline 1994 & $\$ 23,753.53$ & $\$ 9,240$ & $\$ 9,240$ & $38.9 \%$ & $38.9 \%$ \\
\hline 1995 & $\$ 24,705.66$ & $\$ 9,240$ & $\$ 9,240$ & $37.4 \%$ & $37.4 \%$ \\
\hline 1996 & $\$ 25,913.90$ & $\$ 9,500$ & $\$ 9,500$ & $36.7 \%$ & $36.7 \%$ \\
\hline 1997 & $\$ 27,426.00$ & $\$ 9,500$ & $\$ 9,500$ & $34.6 \%$ & $34.6 \%$ \\
\hline 1998 & $\$ 28,861.44$ & $\$ 10,000$ & $\$ 10,000$ & $34.6 \%$ & $34.6 \%$ \\
\hline 1999 & $\$ 30,469.84$ & $\$ 10,000$ & $\$ 10,000$ & $32.8 \%$ & $32.8 \%$ \\
\hline 2000 & $\$ 32,154.82$ & $\$ 10,500$ & $\$ 10,500$ & $32.7 \%$ & $32.7 \%$ \\
\hline 2001 & $\$ 32,921.92$ & $\$ 10,500$ & $\$ 10,500$ & $31.9 \%$ & $31.9 \%$ \\
\hline 2002 & $\$ 33,252.09$ & $\$ 11,000$ & $\$ 12,000$ & $33.1 \%$ & $36.1 \%$ \\
\hline 2003 & $\$ 34,064.95$ & $\$ 12,000$ & $\$ 14,000$ & $35.2 \%$ & $41.1 \%$ \\
\hline 2004 & $\$ 35,157.10$ & $\$ 13,000$ & $\$ 16,000$ & $37.0 \%$ & $45.5 \%$ \\
\hline 2005 & $\$ 36,599.68$ & $\$ 14,000$ & $\$ 18,000$ & $38.3 \%$ & $49.2 \%$ \\
\hline 2006 & $\$ 38,137.06$ & $\$ 15,000$ & $\$ 20,000$ & $39.3 \%$ & $52.4 \%$ \\
\hline
\end{tabular}

Source: Internal Revenue Code and Social Security Administration Trustees Report 2005 
In addition to administering tax-deferred retirement accounts for their employees, most employers (over 90 percent in 1999; Holden and VanDerhei 2001) also contribute to them.

Sometimes employers contribute a constant percentage of wages for all participating employees, while in other plans the employer contribution amount varies with the amount of the employee's contribution. Non-discrimination rules in the tax law require broad participation of employees at different wage levels for plans to qualify for tax deferral. These non-discrimination rules encourage employers to subsidize participation by low-wage workers because without broad participation the plans would not qualify and the owners and their high-wage employees would not be able to take advantage of the tax benefits. ${ }^{2}$

\section{Earlier Findings on Factors Affecting Contribution Rates to 401k Plans}

Research interest in the savings behavior of participants in self-directed retirement accounts has grown in recent years, as defined contribution accounts have become an increasingly important share of retirement income for the elderly and firms continue to shift the responsibility of saving for retirement to individuals. These studies focus mainly on the importance of individual and household level characteristics, firm characteristics and plan design on employee contribution choices.

The most important determinants of individual contributions are age, gender, education, job tenure, income, and planning horizon or taste for saving (Holden and VanDerhei 2001; Munnell, Sunden, and Taylor 2003; General Accounting Office 2001; Congressional Budget Office 2003). Contributions vary positively with age, education, job tenure, and income.

The importance of age reflects in part life-cycle patterns of saving. Economic theory suggests that individuals will save more towards the latter end of their working careers when their earnings are typically higher (based on age earnings-curves) relative to their living expenses (such as child care). In addition, older employees nearing the end of their working life are generally more aware of the need to save for retirement than young workers.

In the aggregate, more men than women participate in $401 \mathrm{k}$ plans and men contribute more to their plans on average than women. Some explanations for these differences include that women earn less than men on average and are more likely to work in jobs that do not offer pension benefits (e.g., part-time positions, positions in small firms, positions in the service industry). Clark et al. (2000), however, found that among 401k participants, women contribute a higher proportion of their earnings than do men with similar earnings (see also Huberman et al., 2003).

Studies show that job tenure has a positive and significant effect on 401k contribution rates (Choi et al. 2002; Madrian and Shea 2001; Munnell, Sunden, and Taylor 2003). Job tenure, which is highly correlated with age, is associated with being fully vested in company pension plans and employee knowledge of firm retirement plans. Compared to less educated workers, higher educated employees are generally more aware of the need for saving for retirement and are more knowledgeable about the advantages of tax-sheltered 401k plans and how to use them.

\footnotetext{
${ }^{2}$ Employers with SIMPLE retirement plans avoid the restrictions of the non-discrimination rules, but workers are subject to lower limits as well. We cannot tell the specific plan type from our data. While this is a limitation in our data, SIMPLE plans are relatively new and not nearly as common as $401 \mathrm{k}$ and $403 \mathrm{~b}$ plans with the higher limits.
} 
Not surprisingly, contribution rates also rise with income. High earners are less liquidity constrained than low earners and thus able to put away larger portions of their income into savings. However, the relationship between income and contributions is complicated because employee contributions are limited by statutory and/or plan-specific amounts, as we discuss below.

Finally, studies show that certain people have a greater taste for saving and that this characteristic is an important determinant of contribution behavior, even when controlling for other factors. For example, in their study of 401k participants, Munnell, Sunden, and Taylor (2003) concluded that individuals' planning horizon was the most important factor affecting employees' participation and contribution decisions.

In addition to individual characteristics, recent studies document the importance of plan features in influencing employee contribution rates. Several key elements in 401k plan design affect employee contribution decisions: default contribution rates (Madrian and Shea 2001; Choi et al. 2004a; Choi et al.2004b), employer match rates, and match thresholds (Andrews 1992; Besset et al.1998; Papke and Poterba 1995; Even and Macpherson 1997; Kusko et al., 1998; Papke, 1992; Huberman et al., 2003; Choi et al. 2002; Englehardt and Kumar 2003), maximum contribution rates (Choi et al 2002), loan provisions (General Accounting Office 1997; Holden and VanDerhei 2001), and investment options (Papke 2004; Cunningham and Englehardt 2002; Huberman et al. 2003). Contributions are also affected by whether or not the employee has access to a defined benefit pension plan, either from her current or a previous employer (Cunningham and Englehardt 2002; Clark and Schieber 1998; Huberman et al. 2003).

Some recent studies (Choi et al. 2004c) found evidence that the take-up rate on 401k plans is much higher when employers automatically deposit money in the plan, with an option for employees to opt out, than when the employee is simply offered an opportunity to contribute. Others have proposed plans to increase the default contribution rate of employees gradually as their earnings increase, so that higher contribution rates reduce the increase in take-home pay from a pay raise instead of reducing take-home pay in absolute terms (Bernatzi and Thaler 2004).

Participants exhibit a strong tendency to contribute at plan-specific limits such as the default rate, the match threshold, and the maximum contribution limit. Choi et al. (2004) conclude that these plan limits are the most important features of plan designs affecting participant contributions. In addition, both loan provisions and investment choice are found to increase contributions to defined contribution plans. The evidence on the effect of employer match rates is much less conclusive. Results seem to vary depending upon the type of data that are used, whether the researcher analyzes average contribution rates or individual contributions, and whether the analysis controls for match thresholds. However, two recent papers on this topic, Englehardt and Kumar (2003) and Choi et al. (2002), offer strong evidence that a higher match rate combined with a higher match threshold lead to higher contribution rates. Finally, the evidence for the influence of defined benefit plans is also somewhat mixed. Cunningham et al. (2002) find that defined benefit coverage has a negative effect on 401k contributions, Clark and Shieber (1998) find no effect, and Huberman at al. (2003) find a positive effect. Munnell, Sunden, and Taylor (2003) find that the level of wealth in a defined benefit account has a negative but insignificant effect on $401 \mathrm{k}$ contributions. 
While several studies have examined the influence of individual, plan and firm characteristics on employee contribution rates to $401 \mathrm{k}$ accounts, only a hand ful have explored the impact of statutory limits on contributions to tax-advantaged retirement accounts. Furthermore, of the few that do exist, all are based on cross-sectional data that look only at one time point and thus cannot evaluate how contribution rates have changed over time with changes in statutory maximums. Most studies show that the statutory limit constrains only a small minority of defined contribution participants. According to a number of studies, (General Accounting Office 2001; Congressional Budget Office 2003; Holden and VanDerhei 2001; Munnell and Sunden 2004) fewer than 10 percent of DC participants contributed up to the statutory maximum in any given year since $1997^{3}$. Thus, only a small minority of contributors in any year would potentially benefit directly from an increase in any of the statutory maximums. Higher earners were more likely than low and moderate earners, older workers more likely than young workers, men more likely than women, and married people were more likely than single earners to contribute the maximum. In contrast, the General Accounting Office (2001) found that increasing the percentage limit (which previously stood at $25 \%$ of salary) on combined employer and employee contributions would benefit low and moderate earners and women the most and accounted for half of the estimated 3.1 million likely direct beneficiaries of an increase in all three contribution limits.

Because the limit appears to constrain few workers, many observers believe that increasing it would have relatively little impact on retirement preparedness (Orzag 2005). But a substantial number of workers contributing less than the statutory limit may be prevented from increasing their contributions by limits their employers impose that are lower than the statutory limit (Joulfaian and Richardson 2001). A study by the Investment Company Institute (2000), based on a survey of 1,851 households, found that while only 11 percent of DC plan participants were contributing at the statutory maximum, 27 percent were contributing the maximum set either by the statutory maximum or by their employer plan in 1999. Similarly, Holden and VanDerhei (2001) find that 52 percent of those contributing less than the statutory limit were constrained by a lower plan-imposed limit (Holden and VanDerhei 2001). In many cases, lower plan limits are due to federal antidiscrimination laws that are designed to prevent employers from tailoring their plans to benefit key executives, while excluding rank and file workers. The rules are complicated, but in general they limit contributions by highly compensated employees to a fraction of what other employees contribute. Increasing the statutory limit on employee contributions could induce some employers to increase their plan-specific contribution limits, which would enable more workers to contribute up to the statutory limit. Such increases would disproportionately benefit higher earners, but some argue that low and moderate-earning workers may benefit indirectly if they encourage some employers to form new plans that would extend pension coverage to more employees, expand pension coverage in existing plans, and/or increase their contributions for low and moderate earning participants in existing plans. These effects, however, are very difficult to measure.

\footnotetext{
${ }^{3}$ Using data from the Survey of Consumer Finances, the General Accounting Office (2001) found that 8 percent of all DC participants contributed up to the statutory maximum in 1998; Using data from individual tax returns, the Congressional Budget Office (2003) found that only 6 percent of participants contributed the statutory maximum in 1997; Using data from a household survey conducted by EBRI and ICI, Holden and VanDerhei (2001) limited their sample to those earning more than $\$ 40,000$ per year and found that within this population, 11 percent contributed the statutory maximum in 1999.
} 


\section{Trends in Participation in Tax-Deferred Retirement Plans}

The share of all workers in jobs that offer tax-deferred retirement plans increased from 47 percent in 1992 to 49 percent in 2001, after dipping to just under 45 percent in 1996 (Table 2). In general, the proportion of workers employed in firms that offer a plan increase with age (except for the oldest age group) and earnings. Between 1992 and 2001, the differences in the shares of workers in jobs offering a tax-deferred plan between old and young workers and between low and high earners increased. In 1992, the gap in the proportion offered a plan between workers age 20-29 and workers age 50-59 was only 6 percentage points (43 percent compared with 49 percent). By 2001, this gap increased to 20 percentage points, with 35 percent of workers age 20-29 in jobs offering such plans compared to 55 percent of workers age 50-59. Similarly, in 1992, 18 percent of workers in the lowest earnings group $(0$ - \$10,000) and 72 percent of workers in the highest earnings group ( $\$ 150,000$ or more) were offered a tax-deferred retirement plan (a 54 percentage point gap); by 2001 the proportions offered a plan had dropped to 11.5 percent for the lowest earners and increased to 85 percent for the highest earners.

Table 2. Percent of Workers in Jobs that Offer 401k Pension Plans and Participation Rate among those Offered a Plan by Year, Age, and Earnings

\begin{tabular}{|c|c|c|c|c|c|c|c|c|c|}
\hline & \multicolumn{3}{|c|}{$\begin{array}{c}\text { Percent of Workers Offered a } \\
\text { 401k Pension Plan }\end{array}$} & \multicolumn{3}{|c|}{$\begin{array}{l}\text { Participation Rate among } \\
\text { Workers Offered a Plan }\end{array}$} & \multicolumn{3}{|c|}{$\begin{array}{c}\text { Participation Rate among } \\
\text { All Workers }\end{array}$} \\
\hline & $1992 * *$ & 1996 & 2001 & $1992 * *$ & 1996 & 2001 & $1992 * *$ & 1996 & 2001 \\
\hline ALL & 0.469 & 0.445 & 0.491 & 0.597 & 0.667 & 0.693 & 0.280 & 0.297 & 0.340 \\
\hline \multicolumn{10}{|l|}{ AGE } \\
\hline $20-29$ & 0.431 & 0.298 & 0.352 & 0.491 & 0.53 & 0.575 & 0.212 & 0.158 & 0.202 \\
\hline $30-39$ & 0.469 & 0.492 & 0.528 & 0.595 & 0.673 & 0.689 & 0.279 & 0.331 & 0.364 \\
\hline $40-49$ & 0.504 & 0.518 & 0.556 & 0.627 & 0.697 & 0.731 & 0.316 & 0.361 & 0.406 \\
\hline $50-59$ & 0.492 & 0.509 & 0.555 & 0.641 & 0.714 & 0.735 & 0.315 & 0.363 & 0.408 \\
\hline $60-69$ & 0.354 & 0.320 & 0.378 & 0.613 & 0.698 & 0.681 & 0.217 & 0.223 & 0.257 \\
\hline \multicolumn{10}{|l|}{ Total Earnings (\$2004) } \\
\hline 0 to 10,000 & 0.179 & 0.085 & 0.115 & 0.131 & 0.27 & 0.338 & 0.023 & 0.023 & 0.039 \\
\hline 10,000 to 25,000 & 0.288 & 0.289 & 0.343 & 0.378 & 0.469 & 0.508 & 0.109 & 0.136 & 0.174 \\
\hline 25,000 to 50,000 & 0.481 & 0.569 & 0.629 & 0.589 & 0.663 & 0.699 & 0.283 & 0.377 & 0.440 \\
\hline 50,000 to 75,000 & 0.656 & 0.736 & 0.758 & 0.654 & 0.773 & 0.801 & 0.429 & 0.569 & 0.607 \\
\hline 75,000 to 100,000 & 0.763 & 0.782 & 0.800 & 0.776 & 0.81 & 0.843 & 0.592 & 0.633 & 0.674 \\
\hline 100,000 to 130,000 & 0.747 & 0.804 & 0.855 & 0.816 & 0.875 & 0.904 & 0.610 & 0.704 & 0.773 \\
\hline 130,000 to 150,000 & 0.747 & 0.818 & 0.796 & 0.762 & 0.824 & 0.869 & 0.569 & 0.674 & 0.692 \\
\hline $150,000+$ & 0.718 & 0.765 & 0.825 & 0.846 & 0.77 & 0.804 & 0.607 & 0.589 & 0.663 \\
\hline
\end{tabular}

**Note: The SIPP pension topical module survey changed between 1992 and 1996. The 1992 survey asked respondent if they were offered a 401k or Thrift plan. The 1996 and 2001 survey probes for a greater range of DC plans including 401k, pre-tax, salary reduction, and 403b plans. The 1992 numbers based on 15,855 workers age 25 to 69 who match the DER. The 1996 numbers are based on 32,028 workers age 20 to 69 in 1997 who match the DER. The 2001 numbers are based on 20,149 workers age 20 to 26 in 2003 who match the DER. Workers are respondents with positive DER earnings. Participants are workers with deferred contributions.

Source: Urban Institute tabulation of the 1992, 1996, and 2001 SIPP linked to the DER.

In addition to being more likely to work for an employer who offers a plan, older workers and workers with higher earnings are also more likely to participate (defined as contributing in that year), given an offer, than younger workers and workers with lower earnings. In contrast to trends 
in offer rates, however, there has been a significant increase in participation rates (conditional on being offered a plan) for all age and income groups.. Among workers ages 20-29, participation rates increased from 49 percent in 1992 to 58 percent in 2001. For workers earning less than $\$ 10,000$ per year, participation rates increased from 13 to 34 percent.

Combining the effects of employer offers and employee take-up, the percentage of workers who participate in a plan increased from 28 percent in 1992 to 34 percent in 2001. Participation rates increased by a much larger percentage for older than for younger workers. The percentage rate of growth in participation was also generally faster for low-income workers than for high-income workers; groups with earnings less than $\$ 75,000$ all had participation rate growth over 40 percent between 1990 and 2001, while the growth rates were less than 30 percent for all groups with earnings over $\$ 75,000$. But because the percentage increases for the low-income groups were on top of a much smaller initial participation rate, the absolute gap in participation rates between the highest and lowest earners widened.

Table 2 displays rates of access to and participation in plans, but not levels of contributions. Previous research with the data set used in this paper has confirmed earlier findings that most employees who participate do not contribute the maximum amount allowable under the tax law. Moreover, Smith, Johnson, and Muller (2004, Table A.4) show that the average contribution amount in 2001 was $\$ 3,637$, far below the legal maximum in that year of $\$ 10,500$. Average contribution amounts were much higher for groups with higher earnings.

\section{Why Contributors May Make Less than the Maximum Contribution}

Contributors may invest less than the legal maximum in tax-deferred accounts because of individual choices and limits in employer plans. Individuals may choose to consume more in the present and forego part of the opportunity for tax-advantaged saving if real or perceived immediate spending needs are sufficiently pressing to outweigh the tax benefits. Employees also may wish to maintain some savings outside of retirement accounts because they are easier to access in an emergency and can be spent without incurring a withdrawal penalty. They may reduce their contributions temporarily because of personal hardship, such as a temporary spell of unemployment, divorce, or health problems, or to finance large, intermittent expenses, such as college tuition or a down payment on a home. As discussed above, employee contributions are also limited when employers set the maximum individual contribution below the maximum in the tax law to keep their plans from violating anti-discrimination rules.

\section{DATA SOURCES}

Most of the studies of contributions to tax-deferred plans reviewed in the previous section are based on either 1) national cross-sectional or panel data, 2) plan data from a few select firms, or 3 ) government-based individuat-level data on tax-deferred contributions. The main benefit of using cross-sectional data sets such as the Current Population Survey (CPS), the Survey on Income and Program Participation (SIPP) or the Health and Retirement Study (HRS) is that they contain information on individual and household characteristics that affect saving, while plan data and tax return data contain very little information on individual characteristics. The main advantage of plan data is the inclusion of detailed and accurate information on pension benefits and formulas. Tax 
return data include information on tax-deferred contributions over a long period of time and are more accurate sources of earnings and contributions than survey data.

For this research, we are able to combine the strengths of cross-sectional data and tax data to analyze changes in contributions to $401 \mathrm{k}$ accounts over time. The data in this paper come from the 1996 SIPP, linked to administrative data from the Social Security Administration's Detailed Earnings Records (DER). The SIPP provides basic demographic and economic information, including age, race, gender, marital status, education, employment status, and income for a nationally representative sample of over 36,000 households. Special topical modules in the SIPP provide additional information on marital histories, fertility histories, employment histories, disability, wealth and its allocation among asset types and, of particular usefulness for our purposes in this paper, characteristics of employer-sponsored pensions.

The DER contains information collected from Internal Revenue Service (IRS) form W-2, which employers must file to report salaries and benefits they pay to their workers. The data are reported separately for wage and salary employees and the self-employed. The dataset provides annual information on total earnings, earnings covered by Social Security, taxable earnings, and tax-deferred contributions to employer-sponsored retirement accounts between 1990 and 2003. ${ }^{4}$

We use the SIPP data merged with administrative earnings records to create a longitudinal sample extending between 1990 and 2003. For each individual respondent in each year, the sample includes measures of pre-tax earnings and individuals' contributions to employer-sponsored retirement plans, as well as the individual's age, gender, race, and education level. The sample also includes marital status through the SIPP interview and earnings and retirement contributions in every year of the person's spouse at the time of the SIPP interview.

Because the data do not contain information on employer contributions, we limit our analysis to individual contributions to $401 \mathrm{k}$ plans. We define individuals as contributing the maximum allowable amount in a given year if their contributions were equal to or exceeded any of the three limits in that year ${ }^{5}$. Because we lack detailed data on the characteristics of employer plans, however, we cannot be certain whether an employee who is contributing less than the statutory maximum is doing so voluntarily or is constrained by the company's plan. The tables shown below cannot distinguish whether employees voluntarily limit their contributions to less than the legal maximum or are constrained by limits in employer plans.

We restrict the sample to workers ages 20 to 69 that contribute to a tax-deferred retirement plan. We exclude workers younger than 20 because many employers do not allow them to

\footnotetext{
${ }^{4}$ We restrict the data set to include only those respondents to Wave 7 of the 1996 SIPP who allowed their responses to be matched to the Social Security administrative data. About 16 percent of Wave 7 respondents do not have a match, primarily because they refused to report their Social Security numbers. Information on retirement plan contributions correspond to codes $d$ through $h$ in box 13 on the W-2 form: 401(k), SIMPLE, 403(b), 408(k)(6), SEP, 457(b), and 501(c)(18)(D) plans. To protect privacy of taxpayers, only researchers who obtain special permission from SSA can access the DER and the data can be analyzed only at secure computing facilities maintained at SSA offices.

${ }^{5}$ The percent of compensation limit prior to 2002 was set at 25 percent and could limit low-earning individuals to lower maximum contribution limits than those set by the legal employee dollar limit. For example, individuals earning less than $\$ 40,000$ a year in 1998 would be bound by the percent of compensation limit prior to meeting the $\$ 10,000$ employee dollar limit in that year.
} 
participate in retirement plans and we exclude workers older than 69 because people must begin withdrawing funds from defined contribution plans at age 70 and a half. Our sample includes 120,875 (person-year) observations between 1990 and 2003.

For those who participate, we can calculate average contributions and the percentages of the population and of population sub-groups who contribute the maximum amount or an amount above any given threshold level or percentage of earnings. This gives us an opportunity to examine the extent to which participants take full advantage of the tax-preferred saving opportunity available to them and how the degree of utilization of the tax preference has changed over time, both for the entire population and for sub-groups of the population

The two main limitations of the dataset are that it does not fully describe how demographic and economic circumstances of individuals have changed throughout the years of the sample and provides only limited data on employer contributions. The SIPP data, for example, do provide some information on marital circumstances prior to the survey years, but do not indicate changes in marital status after 1999. SIPP does not indicate whether the employer offered a defined contribution retirement plan in years other than 1997, although it is unlikely that coverage that existed in the sample year ceased afterwards if the worker remained with the same firm. The dataset also does not reveal whether those who contribute less than the maximum amount allowable by law do so voluntarily or are constrained by limitations in their company plan.

\section{GROWTH IN PERCENTAGE OF WORKERS CONTRIBUTING MAXIMUM AMOUNT}

In this section, we examine the growth between 1990 and 2003 in the percentage of participating workers who contribute the maximum allowable amount and in the percentage of workers who are "high contributors," defined as those who contribute either 10 percent of earnings or the maximum amount. We show how the percentage contributing the maximum varies by age across cohorts (years) and by cohorts (years) within age groups. We then compare growth rates over time within groups classified by age, income, gender, education level, race/ethnicity, marital status, and the presence of self-employment income. We illustrate how inequality in maximum participation rates between higher and lower participation rate sub-groups has increased over time and present regression results that explain the growth in both those contributing the maximum amount and "high contributors" as a function of earnings and demographic characteristics.

\section{Overall Trends}

The percentage of participants who contribute the maximum amount increased from 3.5 percent in 1990 to 7.5 percent in 2001 (Figure 1). The percentage at the maximum then dipped to 6 percent in 2003 because some workers ages 50 and over did not take advantage of the provisions allowing them to make additional "catch-up" contributions. Excluding the catch-up provision, the percentage of contributors at the maximum remained roughly constant between 2001 and 2003.

The growth in the percentage contributing the maximum reflects both age and cohort effects. Between 1990 and 2001, older workers were more likely to contribute the maximum amount than younger workers, with workers under age 30 least likely to contribute the maximum and workers ages 50 and over most likely to contribute the maximum (Figure 2). After 2001, the percentage of 
Figure 1. Percent of Participants Contributing Maximum to 401k With and Without the Over 50 Catch-Up Contribution

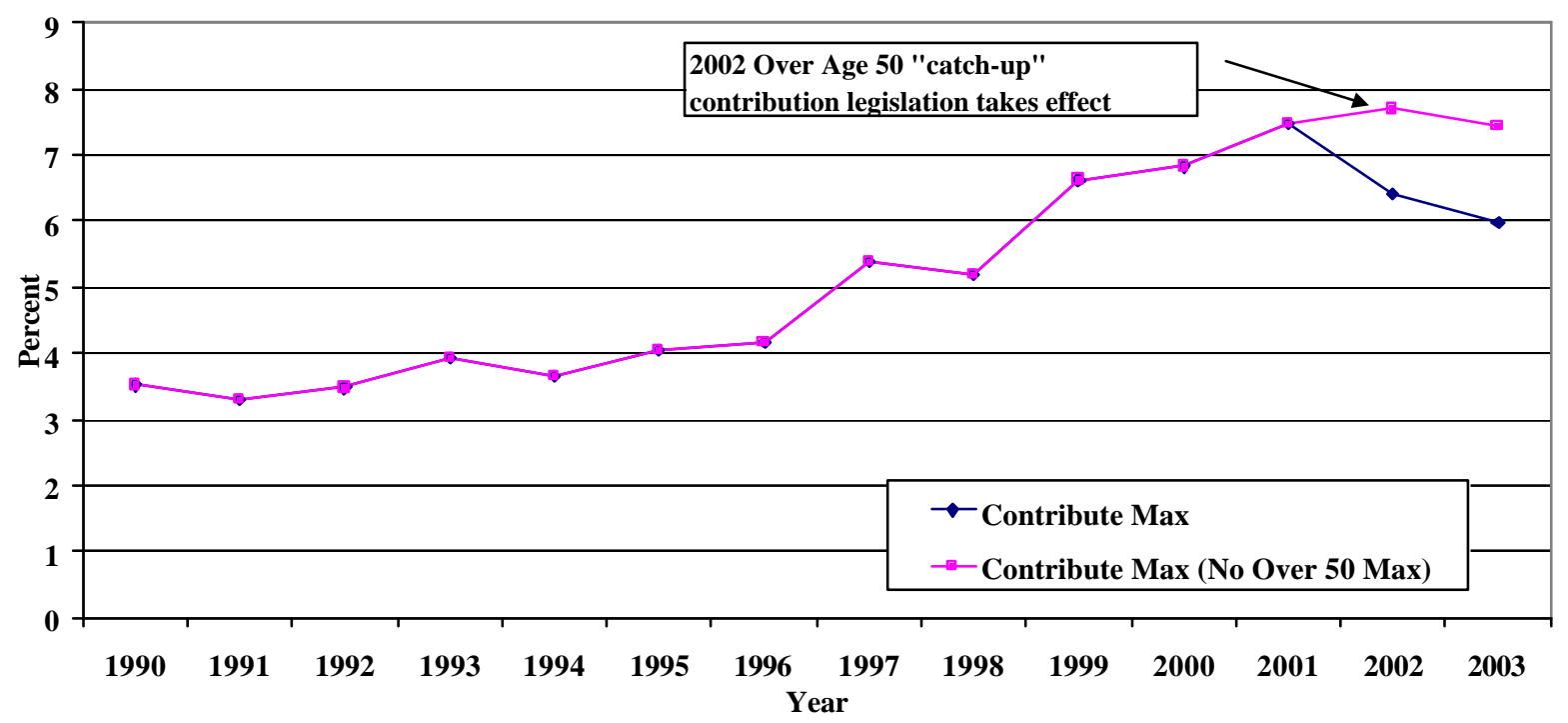

Source: Authors' calculations using 1996 SIPP matched to the Detailed Earnings File.

See Appendix Table A1.

Figure 2. Percent of Participants Contributing Maximum to 401k by Age and Year

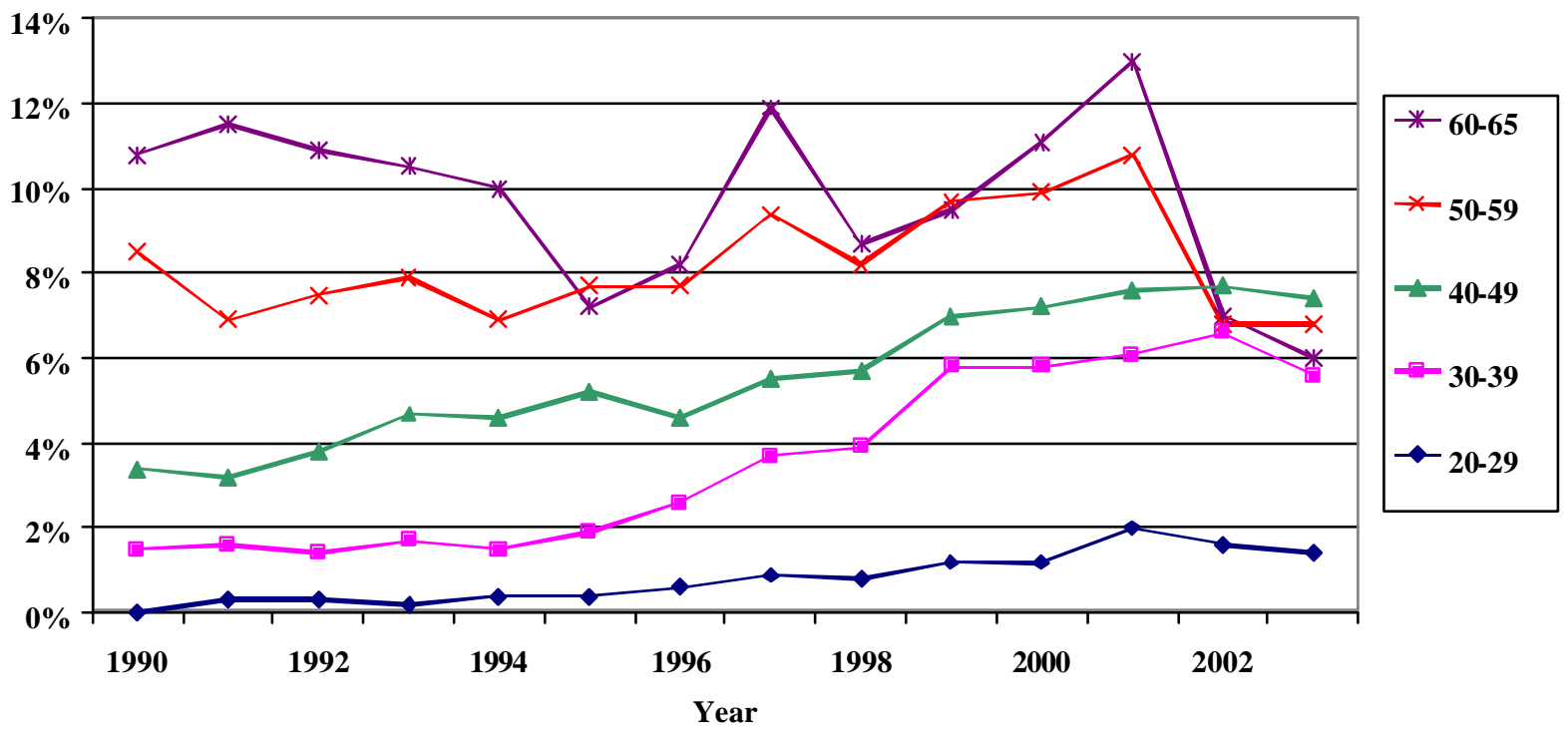

Source: Authors' calculations using 1996 SIPP matched to the Detailed Earnings File.

See Appendix Table A1.

workers over age 50 at the maximum declined sharply due to the over-50 catch-up provisions, but, excluding the catch-up provisions, workers over age 50 remained more likely to contribute the maximum than younger workers (Figure 3 ). Throughout the sample period, the percentage at the 
maximum for most age groups increased over time, reflecting an increased propensity for later cohorts of workers to contribute the maximum amount.

In general, workers in a given birth cohort became more likely to contribute the maximum as they became older (Figure 4). At any given age, workers in more recent birth cohorts (later years in the period) were more likely to contribute the maximum than workers in earlier birth cohorts.

Figure 3. Percent of Participants Contributing Maximum to 401k (without Over 50 Catch-up Contribution) by Age and Year

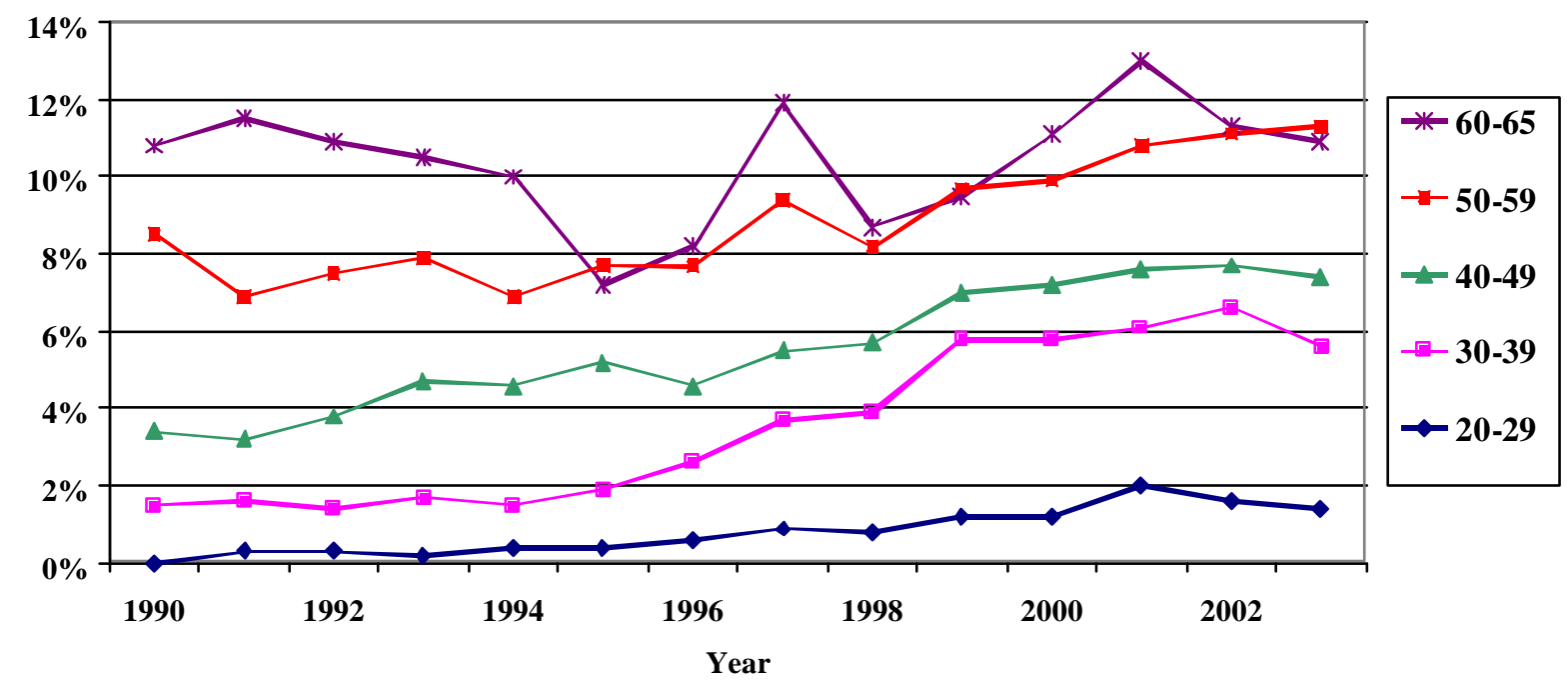

Source: Authors' calculations using 1996 SIPP matched to the Detailed Earnings File.

See Appendix Table A1.

Figure 4. Percent of Participants Contributing Maximum to 401K by Age and Cohort

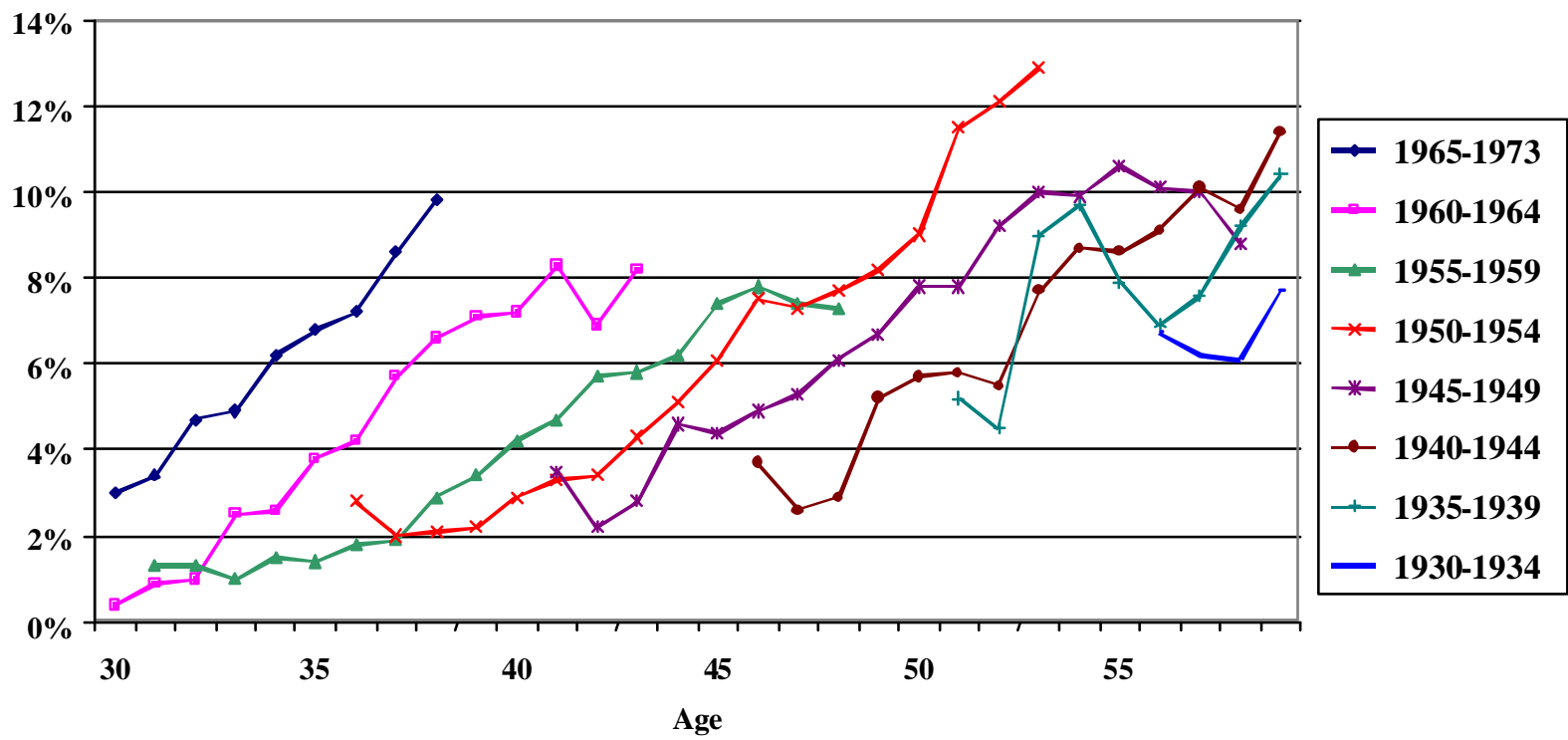

Source: Authors' calculations using 1996 SIPP matched to the Detailed Earnings File.

See Appendix Table A1. 
The probability of contributing the maximum amount is higher among some income and demographic groups than others. Maximum contributors are more prevalent among high income compared with low income workers, college graduates compared with those with less education, non-Hispanic whites and others (principally Asian-Americans) than blacks and Hispanics, and married compared with unmarried people. Our principal finding in this paper is that virtually all the growth in the percentage of workers contributing the maximum amount since 1990 has come from growth in contribution rates among high contributing groups. The result has been to widen the differences in the propensity to contribute the maximum amount among income and demographic groups. The next section of the paper documents this finding.

\section{Detailed Differences in Growth in Maximum Contribution Percentage Among Demographic Groups}

The percentage contributing the maximum amount to tax-deferred retirement accounts differs among groups classified by income, gender, education, race/ethnicity, marital status, and the presence of self-employment income. Between 1990 and 2003, the percentage contributing the maximum in groups with the highest maximum participation rates increased, while the percentage contributing the maximum was largely unchanged for other groups.

Contributions by Earnings. In 1990, the percentage contributing the maximum amount increased with increases in income (Figure 5). The percentages contributing the maximum amount were between 1 and 3 percent for workers with earnings under $\$ 75,000,7$ percent for workers with earnings between $\$ 75,000$ and $\$ 100,000,23$ percent for workers with earnings between $\$ 130,000$ and $\$ 150,000$, and 47 percent for workers with earnings over $\$ 150,000$. Over the 1990-2003 period, the percentage at the maximum remained about the same for workers earning less than $\$ 75,000$, but increased to 12 percent for workers with earnings between $\$ 75,000$ and $\$ 100,000,38$ percent for workers with earnings between $\$ 130,000$ and $\$ 150,000$, and 53 percent for workers with earnings over $\$ 150,000$. For these latter two groups, the percentage at the maximum declined after 2001 due in large part to the over 50 catch-up contributions. Put differently, employees earning between $\$ 75,000$ and \$100,000 (in 2004 dollars) were about 8 times more likely in 1990 and 31 times more likely in 2003 to contribute the maximum amount than employees with earnings under $\$ 25,000$. Employees earning over \$150,000 were just under 60 times more likely in 1990 and 133 times more likely in 2003 to contribute the maximum amount than employees earning under $\$ 25,000$.

Contributions by Gender. Males are more likely to be maximum contributors than females (Figure 6). In 1990, 4.1 percent of males and 2.8 percent of females were maximum contributions. By 2003, the share of males who were maximum contributors had almost doubled to 8 percent, while the female share of maximum contributions increased by a smaller proportion to 3.6 percent. The higher propensity to contribute the maximum for males is entirely explained by the higher earnings of males. Within every earnings group, females are more likely than males to contribute the maximum amount (Figure 7). 
Figure 5. Percent of Participants Contributing Maximum to 401k by Total Annual Earnings (\$2004)

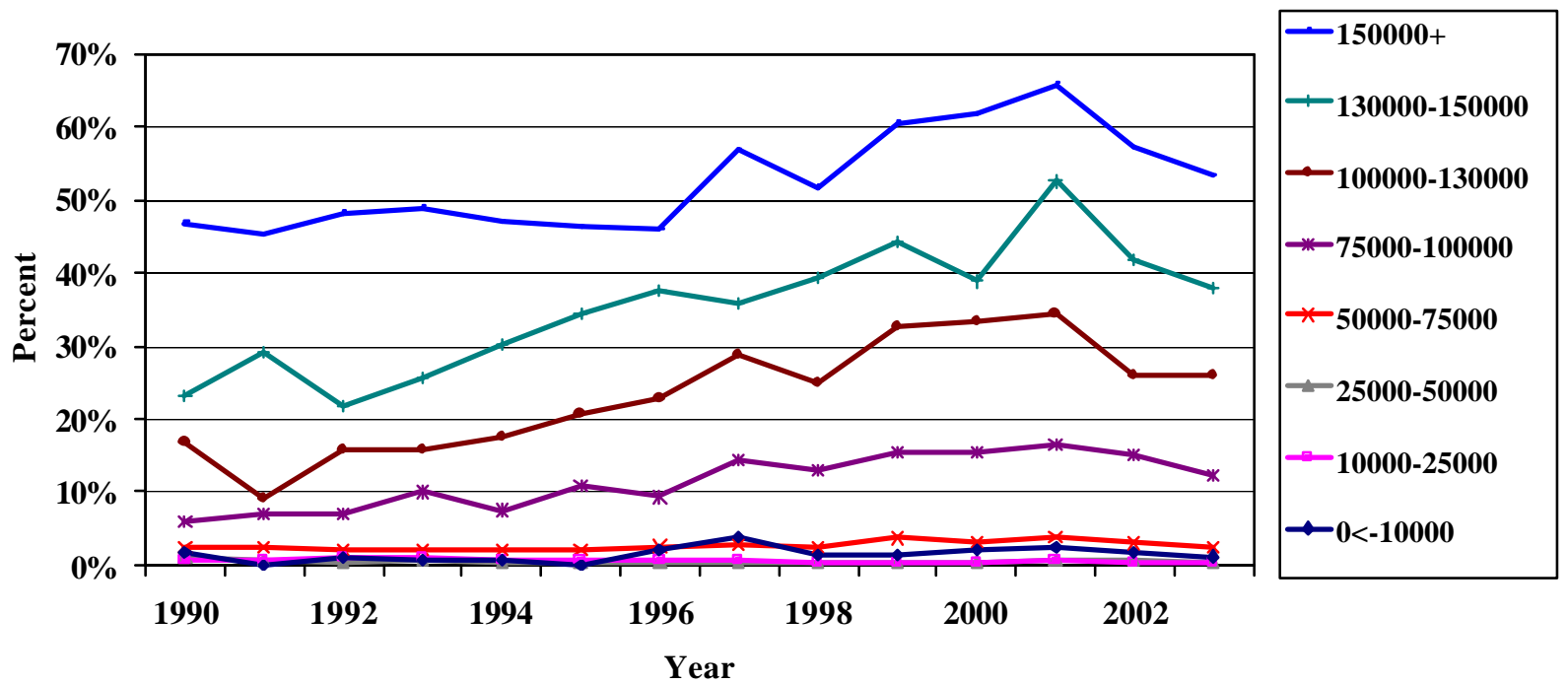

Source: Authors' calculations using 1996 SIPP matched to the Detailed Earnings File. See Appendix Table A1.

Figure 6. Percent of Participants Contributing Maximum to 401k by Sex

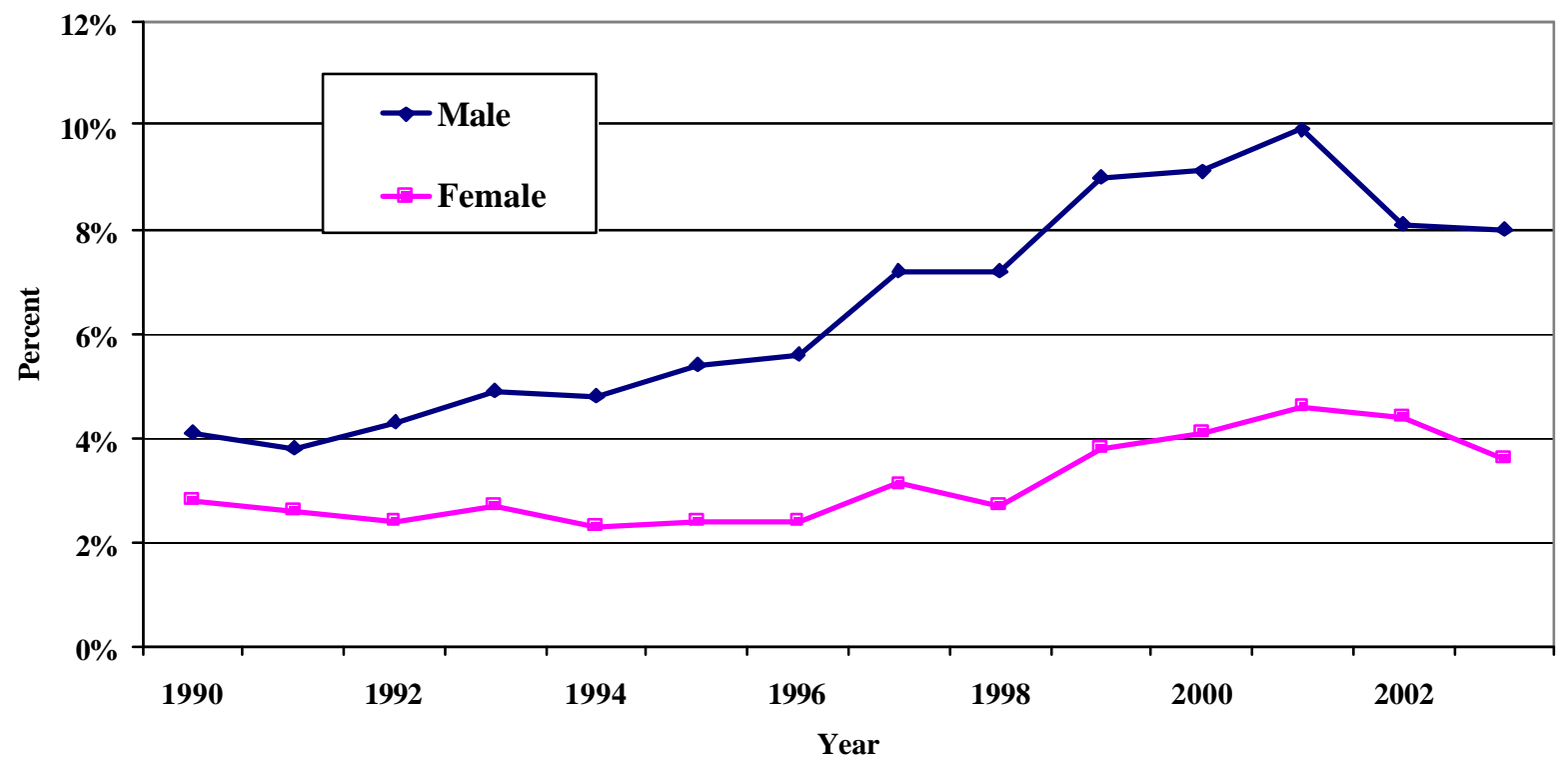

Source: Authors' calculations using 1996 SIPP matched to the Detailed Earnings File. See Appendix Table A1. 
Figure 7. Percent of Participants Contributing Maximum to 401k by Sex and Total Annual Earnings (\$2004)

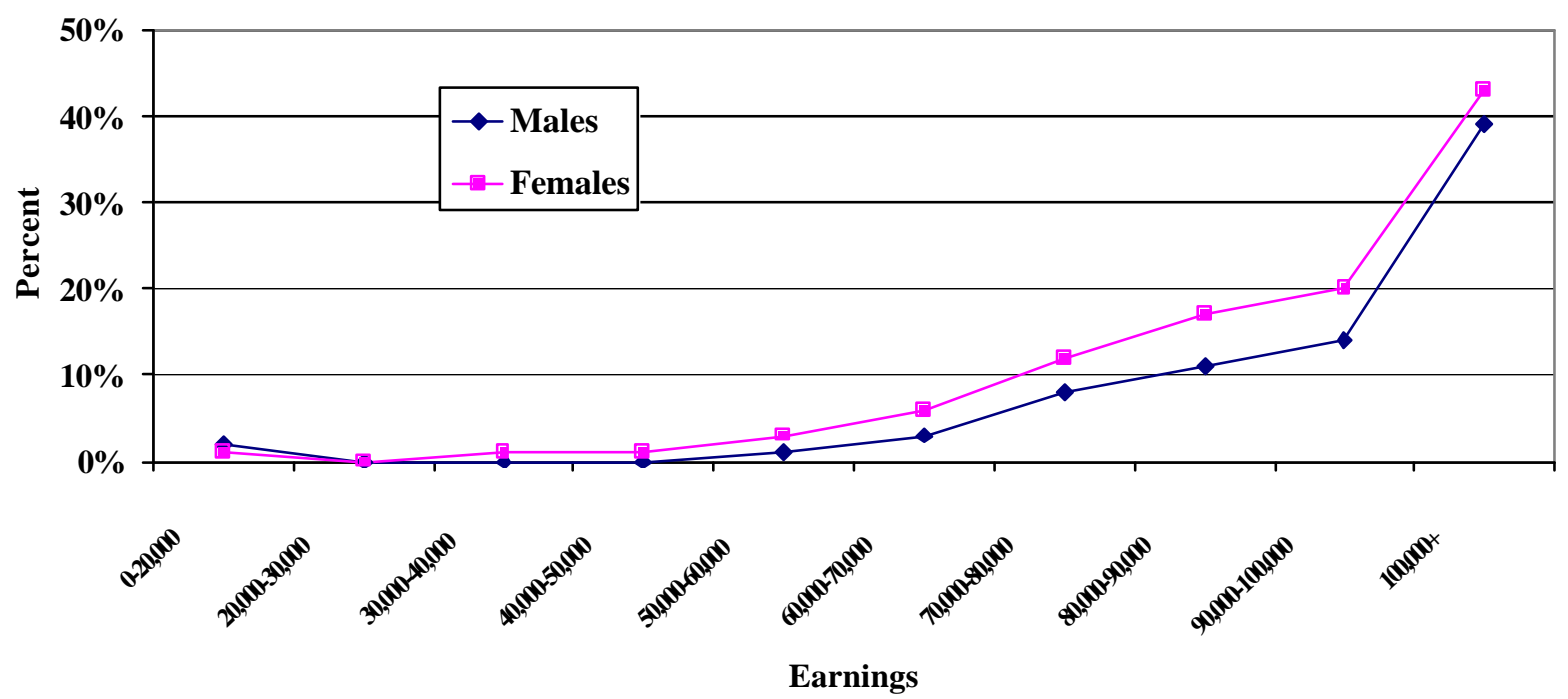

Source: Authors' calculations using 1996 SIPP matched to the Detailed Earnings File.

See Appendix Table A1.

Contributions by Education Level. People with a college degree or more are much more likely to contribute the maximum amount than people with some college, high school graduates, and high school dropouts (Figure 8). Between 1990 and 2003, the percentage of college graduates contributing the maximum amount more than doubled, while the contribution rates for the other education level groups were mostly unchanged. Expressed in terms of ratios, college graduates were about 9 times more likely in 1990 and over 15 times more likely in 2003 to contribute the maximum amount, compared with high school dropouts.

Contributions by Race/Ethnicity. The percentages of non-Hispanic whites and others who contribute the maximum amount is higher in most years than the percentages of Hispanics and nonHispanic blacks who contribute the maximum (however, in 1990, the maximum contribution percentages for non-Hispanic whites and Hispanics were roughly equal). Between 1990 and 2003, the percentage contributing the maximum increased for non-Hispanic whites and other, declined for Hispanics, and increased only slightly for non-Hispanic blacks (Figure 9). Non-Hispanic whites were over twice as likely to contribute the maximum than non-Hispanic blacks in 1990 and over three times as likely to contribute the maximum in 2003. 
Figure 8. Percent of Participants Contributing Maximum to 401k by Educational Attainment

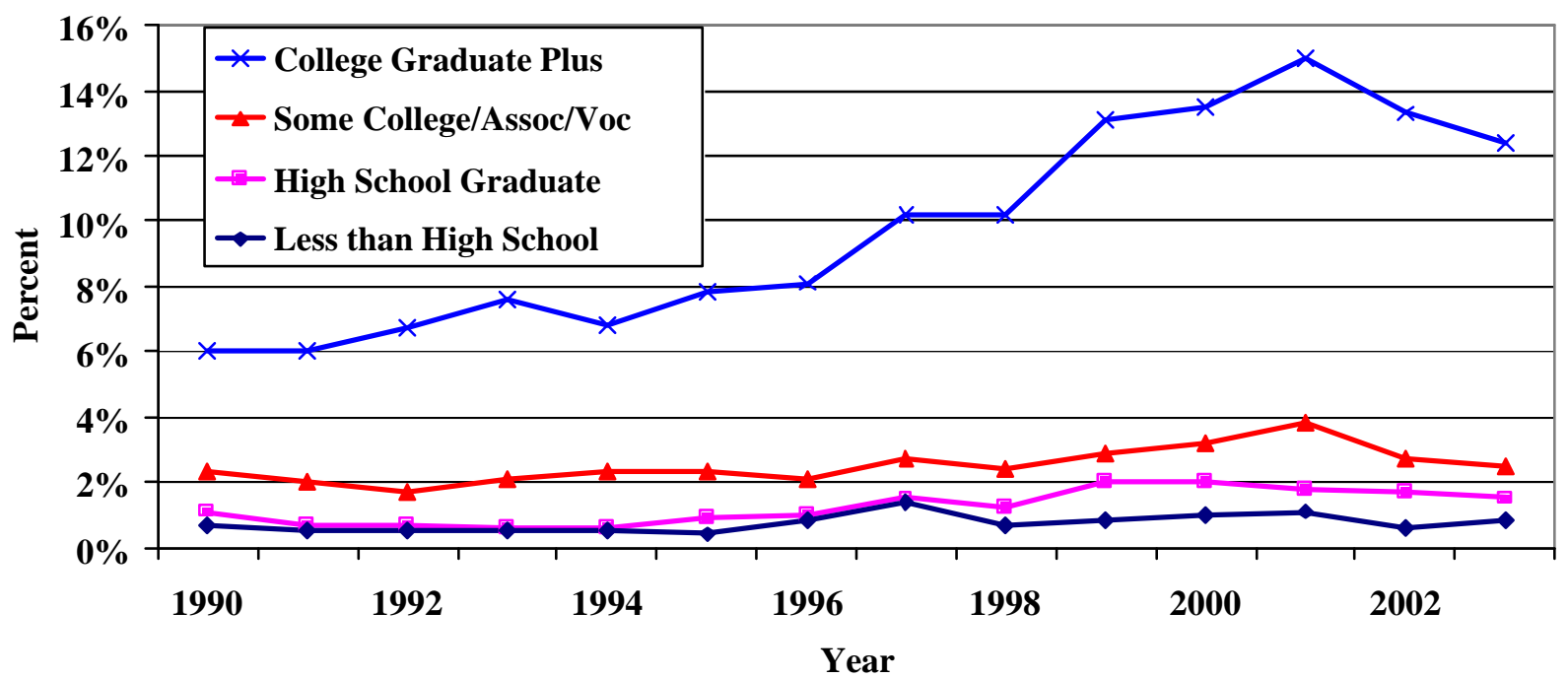

Source: Authors' calculations using 1996 SIPP matched to the Detailed Earnings File.

See Appendix Table A1.

Figure 9. Percent of Participants Contributing Maximum to 401K by Race

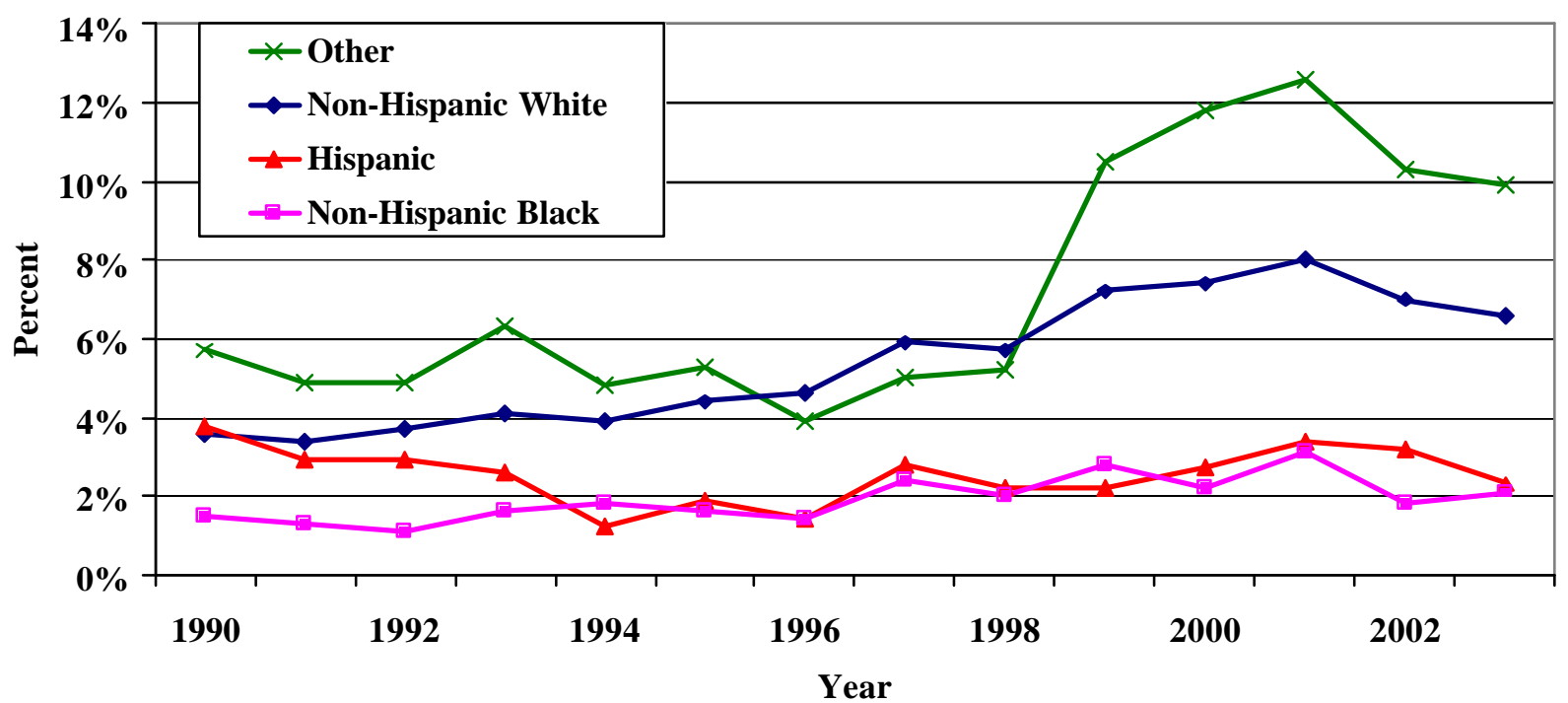

Source: Authors' calculations using 1996 SIPP matched to the Detailed Earnings File.

See Appendix Table A1. 
Contributions by Marital Status. The percentage of married people who contribute the maximum was higher than the percentage of widowed, single, and never married who contribute the maximum for most years between 1990 and 2003 (Figure 10). ${ }^{6}$ The percentage married who contribute the maximum increased from 4 percent in 1990 to 9 percent in 2001, before dropping to 7 percent in 2003. The percentage contributing the maximum also increased for the never-married (from under 2 percent in 1990 to almost 4 percent in 2003), but there was almost no discernible upward trend in the percent contributing the maximum for either widowed or divorced people.

Figure 10. Percent of Participants Contributing Maximum to 401k by Marital Status

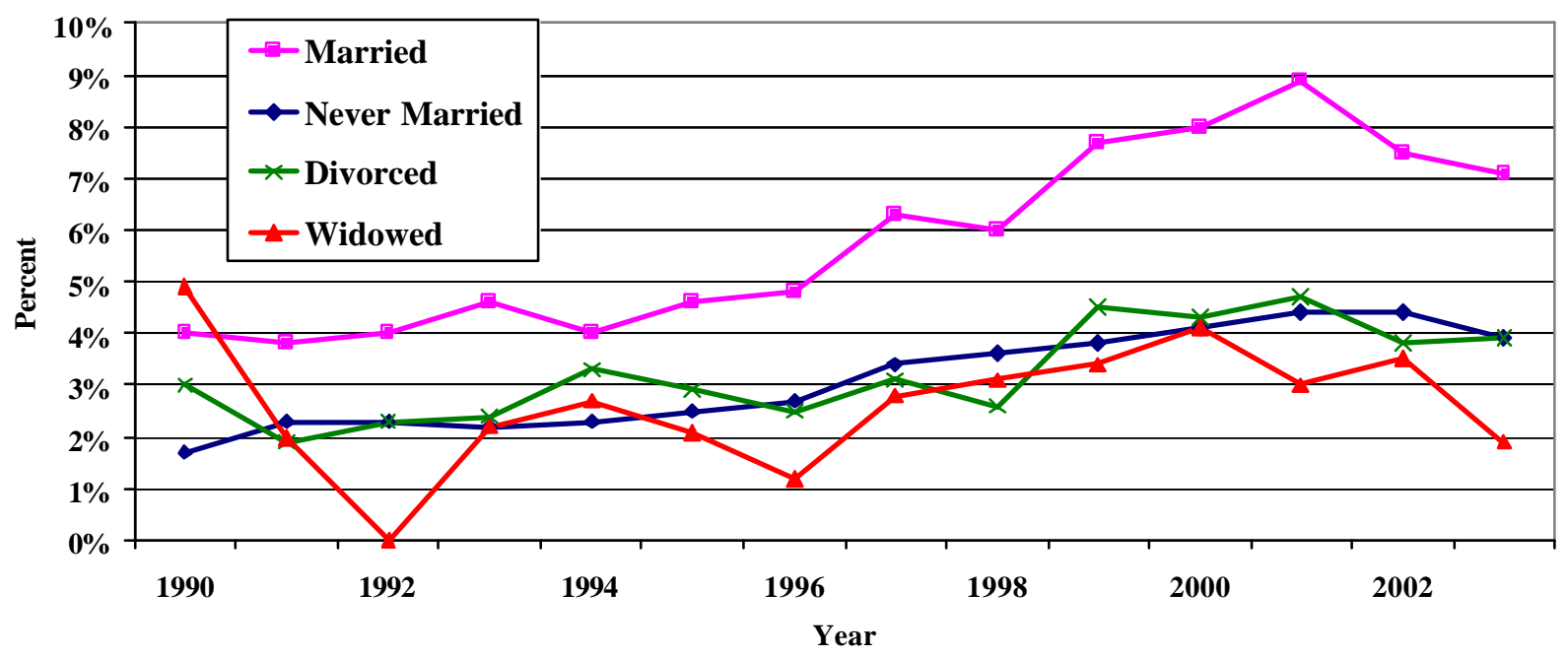

Source: Authors' calculations using 1996 SIPP matched to the Detailed Earnings File.

See Appendix Table A1.

Contributions by Self-Employment Status. Employees who also report self-employment income are more likely to contribute the maximum to their employer-based retirement plan than employees without self-employment income (Figure 11). Over the 2001-2003 period, the percent contributing the maximum increased by a much larger percentage for those with self-employment income than for those without self-employment income. As with gender, the higher probability of contributing the maximum among self-employed is due to the generally higher earnings among workers with self-employment income.

\footnotetext{
${ }^{6}$ The percentage of widowed who contribute the maximum was higher than the percent married who contribute the maximum in 1990, but dropped to zero in 1992. This may reflect a small sample size for the number of workers who are widowed.
} 
Figure 11. Percent of Participants Contributing Maximum to 401k by Self Employment Status (in addition to wages)

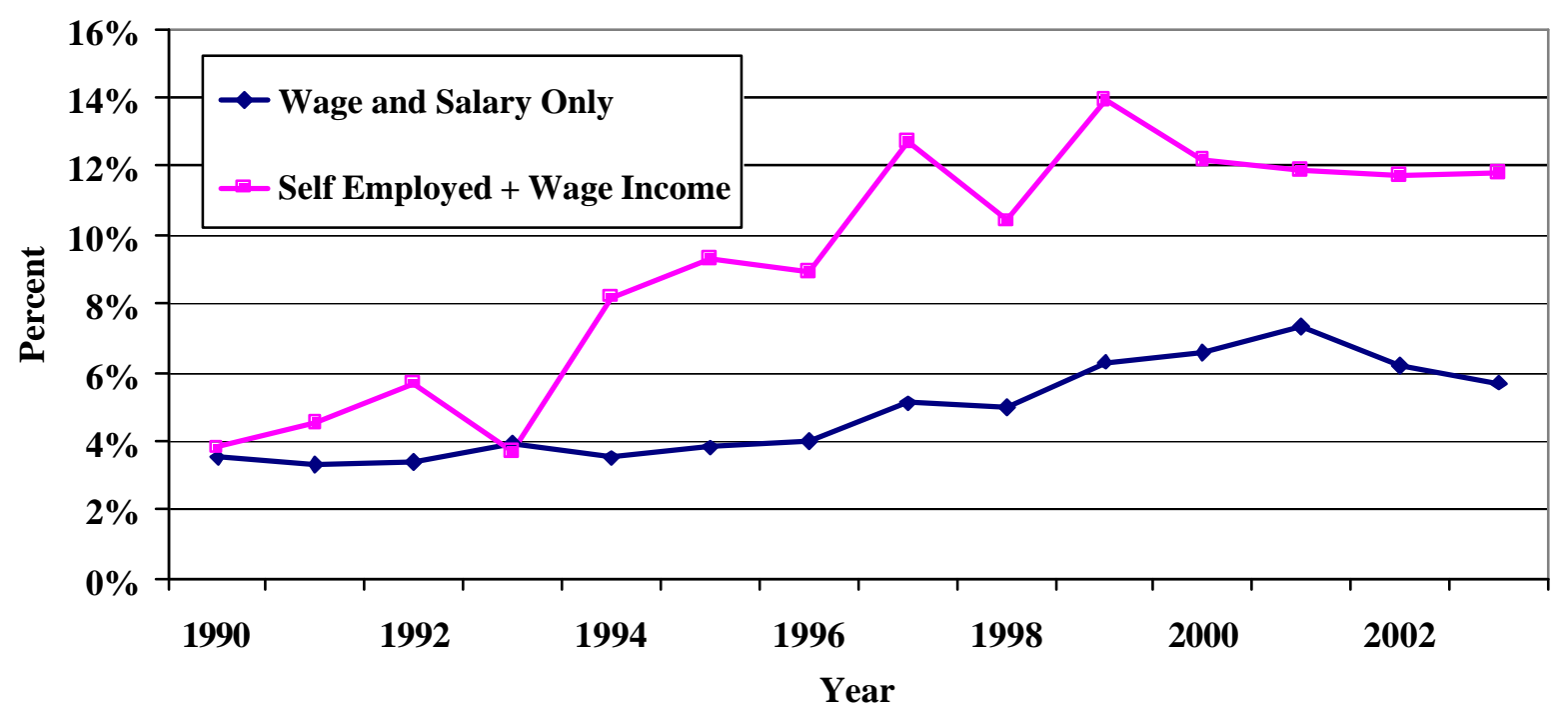

Source: Authors' calculations using 1996 SIPP matched to the Detailed Earnings File.

See Appendix Table A1.

\section{Growth in High Contributors}

As an alternative to measuring the percentage of employees who contributed the maximum allowable amount, we also examined trends in the percentage of participating employees whom we deem to be large contributors. We define a large contributor to be someone who deposits either 1) 10 percent of his or her earnings in a tax-deferred retirement account or 2) the maximum allowable amount. For employees with high earnings, the maximum allowable amount is less than 10 percent of earnings, but we want to count anyone who is contributing as much as possible to be a large contributor. Results from these analyses are presented in the appendix.

Overall, the observed relationships between this alternative measure of large contributions and important social and economic characteristics do not differ significantly from those observed under the original measure of contributing the maximum. Older employees are more likely to be large contributors to tax-deferred retirement plans than younger employees (Table A2). Growth rates in the percent contributing 10 percent or more or the maximum, however, do not show any consistent pattern of difference by age. As expected, the percentage of large contributors increases with the level of annual earnings. The growth rate in percentage of large contributors also rises with the level of earnings. College graduates are more likely to be large contributors than less educated workers and the relative differential between college graduates and the less educated has widened over time. Non-Hispanic whites and others are more likely to be large contributors than Hispanics and non-Hispanic blacks and the differential between these groups has also widened over time.

While only very small percentages of lower contributing groups - less educated, low earners, ethnic minorities and young workers -- contribute the statutory maximum, many do contribute a reasonably large proportion of their annual earnings to their retirement plans and the percentage of large contributors in these groups is rising over time. Between 1990 and 2003, for 
example, the percentage contributing at least 10 percent or more of earnings increased from 11 to 22 percent for those earning less than $\$ 10,000$ per year, from 10 to 13 percent for those earning between $\$ 10,000$ and $\$ 25,000$ per year and from 9 to 15 percent for those earning between $\$ 25,000$ and $\$ 50,000$ per year. Among those with less than a high school education, the share of "large" contributors more than doubled from 5 percent in 1990 to 11 percent in 2003. For ethnic minorities, gains were more modest but still exhibited an upward trend, with the proportion contributing 10 percent or more of their earnings (or the maximum) increasing from 9 percent to 10 percent for nonHispanic blacks and from 10 percent to 12 percent for Hispanics between 1990 and 2003. None of these groups showed any significant gains in the proportion contributing the statutory maximum between 1990 and 2003 .

\section{Factors Contributing to Changes in Percent Contributing Maximum to Tax-Deferral Accounts}

We tested a number of multiple logit regression specifications to explain the factors contributing to the growth in the percentage of participants who deposit the maximum amount in tax-deferred accounts and who contribute at least 10 percent of earnings or the maximum. The equations are not structural representations of the behavior of individuals because we cannot measure whether in any given year an employee worked for a firm that offered a plan allowing the individual to contribute the maximum amount. Instead, the equations show the factors contributing to the growth in maximum participation among those who participate.

In all specifications, the percentages contributing the maximum are higher for married and never-married individuals than for those widowed or divorced, higher for whites and others than for blacks and Hispanics, higher for older than for younger workers, higher for more educated than for less educated workers, and higher for workers with higher earnings, holding other characteristics constant. We also find that higher earnings are associated with larger growth rates in both the percentage contributing the maximum and the share of high contributors.

Single Characteristic Models. We first specified a set of models (Table 3) that include only one economic measure or demographic characteristic (earnings, education, or race). These equations formalize the relationships observed in the graphs displayed in the previous section. All of the single-characteristic models in Table 3 include age dummies, a time trend, and an interaction term between the economic or demographic variable of interest and year that shows the contribution of the characteristic to the growth rate in maximum contributions over time. In all these equations, the share of maximum contributors is positively related to age.

The share of maximum contributors rises with earnings and increases faster over time for employees with higher earnings (Table 3, Model 1). When earnings, age, and the interaction of earnings with time are included as the only explanatory variables, the time trend variable is negative and statistically significant. The same result holds when earnings are represented by earnings group dummy variables instead of by a continuous variable measuring the level of earnings, except that the coefficient on time is now smaller and significant only at the 10 percent level (Table 3, Model 2). Because the model includes interaction terms between earnings and calendar year, this result indicates that for workers earnings less than $\$ 25,000$, the probability of contributing the maximum is decreasing over time. Note that when we specify earnings with a categorical measure in Model 2, 
Table 3: Logit Regression Models for Whether Individuals Contributing to 401k Contribute Statutory Maximum Using Select Independent Variables

\begin{tabular}{|c|c|c|c|c|c|c|c|c|}
\hline \multirow[b]{2}{*}{ Independent Variables } & \multicolumn{2}{|c|}{$\begin{array}{l}\text { Model 1: Earnings } \\
\text { (ln(earnings)) }\end{array}$} & \multicolumn{2}{|c|}{$\begin{array}{l}\text { Model 2: Earnings } \\
\text { (Categorical) }\end{array}$} & \multicolumn{2}{|c|}{ Model 3: Education } & \multicolumn{2}{|c|}{ Model 4: Race } \\
\hline & Coeff. & Stnd.Error & Coeff. & Stnd. Error & Coeff. & Stnd. Erro & Coeff. & Stnd. Error \\
\hline Age $<30$ & (ref cat) & & (ref cat) & & (ref cat) & & (ref cat) & \\
\hline Age 30-34 & $0.5656 * * *$ & 0.1034 & $0.4902 * * *$ & 0.0989 & $1.1134 * * *$ & 0.0981 & $1.2627 * * *$ & 0.0977 \\
\hline Age 35-39 & $0.6450 * * *$ & 0.1001 & $0.5415 * * *$ & 0.0953 & $1.5794 * * *$ & 0.0939 & $1.6490 * * *$ & 0.0933 \\
\hline Age 40-44 & $0.6429 * * *$ & 0.0997 & $0.5566 * * *$ & 0.0946 & $1.7367 * * *$ & $\quad 0.0930$ & $1.7665 * * *$ & 0.0923 \\
\hline Age 45-49 & $0.8948 * * *$ & 0.0988 & $0.8004 * * *$ & 0.0941 & $1.9849 * * *$ & 0.0922 & $2.0226 * * *$ & 0.0915 \\
\hline Age 50-54 & $1.2498 * * *$ & 0.0987 & $1.1412 * * *$ & 0.0949 & $2.2874 * * *$ & $=0.0924$ & $2.3009 * * *$ & 0.0913 \\
\hline Age 55-59 & $1.3937 * * * *$ & 0.1017 & $1.2945 * * *$ & 0.0980 & $2.4463 * * *$ & 0.0946 & $2.3686 * * *$ & 0.0933 \\
\hline Age 60-64 & $1.8191 * * * *$ & 0.1091 & $1.7313 * * *$ & 0.1072 & $2.5988 * * *$ & 0.1005 & $2.4781 * * *$ & 0.0985 \\
\hline Age 65-69 & $2.0444 * * *$ & 0.1524 & $1.9171 * * *$ & 0.1486 & $2.6023 * * *$ & 0.1291 & $2.4287 * * * *$ & 0.1263 \\
\hline Calendar Year & $-0.6251 * * *$ & 0.1139 & $-0.0403 *$ & 0.0224 & $0.0627 * * *$ & 0.0074 & $0.0251 *$ & 0.0144 \\
\hline Log(Earnings) & $2.2450 * * * *$ & 0.0942 & - & -- & -- & -- & -- & -- \\
\hline Year*Log(Earnings) & $0.0613 * * *$ & 0.0100 & - & -- & -- & -- & -- & -- \\
\hline Earnings $<25,000$ & -- & - & (ref cat) & & -- & -- & -- & -- \\
\hline Earnings 25,000-49,999 & -- & - & $-0.4617 *$ & 0.2583 & -- & -- & -- & -- \\
\hline Earnings 50,000-74,999 & -- & - & $0.7492 * * *$ & 0.2195 & -- & -- & -- & -- \\
\hline Earnings 75,000-99,999 & -- & - & $1.9974 * * *$ & 0.2137 & -- & -- & -- & -- \\
\hline Earnings 100,000-124,999 & -- & - & $2.7439 * * *$ & 0.2224 & -- & -- & -- & -- \\
\hline Earnings 125,000-149,000 & -- & - & $3.1956 * * *$ & 0.2403 & -- & -- & -- & -- \\
\hline Earnings $>150,000$ & -- & - & $4.2050 * * *$ & 0.2214 & -- & -- & -- & -- \\
\hline Year*Earnings 25,000-49,999 & -- & - & 0.0357 & 0.0287 & -- & -- & -- & -- \\
\hline Year*Earnings 50,000-74,999 & -- & - & $0.0905 * * *$ & 0.0242 & -- & -- & -- & -- \\
\hline Year*Earnings 75,000-99,999 & -- & - & $0.1224 * * *$ & 0.0236 & -- & -- & -- & -- \\
\hline Year*Earnings 100,000-124,999 & -- & - & $0.1303 * * *$ & 0.0244 & -- & -- & -- & -- \\
\hline Year*Earnings 125,000-149,000 & -- & - & $0.1431 * * *$ & 0.0261 & -- & -- & -- & -- \\
\hline Year*Earnings $>150,000$ & -- & - & $0.1226 * * *$ & 0.0244 & -- & -- & -- & -- \\
\hline Less than College Degree & -- & - & - & -- & (ref cat) & & -- & -- \\
\hline College Degree or Higher & -- & - & - & -- & $1.6689 * * *$ & 0.0851 & -- & -- \\
\hline Year*College Degree or Higher & -- & - & - & -- & $0.0182 * *$ & 0.0084 & -- & -- \\
\hline Black or Hispanic & -- & - & - & -- & -- & -- & (ref cat) & \\
\hline White or Other Race & -- & - & - & -- & -- & -- & $0.4779 * * *$ & 0.1479 \\
\hline Year*White or Other Race & -- & - & - & -- & -- & -- & $0.0532 * * *$ & 0.0149 \\
\hline $\begin{array}{l}\text { Constant } \\
\text { Person-Year Observations } \\
\text { Pseudo R-squared }\end{array}$ & $\begin{array}{c}-29.2420 * * * \\
120875 \\
0.3385\end{array}$ & 1.0639 & $\begin{array}{l}-5.5078 * * * \\
120875 \\
0.3589 \\
\end{array}$ & 0.2098 & $\begin{array}{l}-6.2891 * * * \\
120875 \\
0.1346\end{array}$ & $=0.1125$ & $\begin{array}{l}-5.7743 \text { **** } \\
120875 \\
0.0555\end{array}$ & 0.1656 \\
\hline
\end{tabular}

* Significant at .10 level

*** Significant at .05 level

*** Significant at 01 level 
the results reveal a somewhat bimodal relationship between earnings and contributing the maximum. Compared with employees earning $\$ 25,000$ or less, the probability of contributing the maximum is lower for employees with earnings between $\$ 25,000$ and $\$ 49,999$, but higher, and increasing monotonically with earnings, for employees in all other earnings groups. This dip in the $\$ 25,000$ - $\$ 49,999$ earnings group is attributable to the fact that individuals in the lowest earnings group are likely to hit the percent of compensation maximum at relatively low earnings levels. The growth rate over time (holding age constant) is negative in the lowest earnings group, but is positive in all other earnings groups, reaching a peak for employees with earnings between $\$ 125,000$ and $\$ 149,000$.

Using education level as the measure of economic status, the percentage contributing the maximum amount is higher and grows faster for college graduates than for others, but in this specification the calendar year effect is positive, suggesting some growth in the percent at the maximum even for those without a college degree (Model 3). Using race/ethnicity as the single demographic measure, the percentage at the maximum is higher and increases faster over time for whites and other races than for blacks and Hispanics (Model 4). In this last specification, the calendar year effect is positive, but not statistically significant at the 5 percent level.

Multi-Factor Models. In Table 4, we display the results from full logistic regressions, which include earnings and demographic characteristics in the same equation, along with controls for other important factors influencing the degree of participation ${ }^{7}$. We test interaction terms between earnings and calendar year, which will indicate whether or not the probability of contributing the maximum amount is rising faster for higher earners than lower earners, holding other variables constant. We estimate separate equations for the share of maximum contributors and the share of large contributors (those who contribute 10 percent of earnings or the statutory maximum), both with and without inclusion of a variable for the ratio of the statutory maximum individual contribution to the average wage.

The probability of contributing the statutory maximum and of being a large contributor both depend on gender, marital status, race/ethnicity, education, self-employment status, and earnings. Holding all other variables constant, the share of maximum contributors is:

- Higher for high-earning females than for high-earning males (earnings more than $\$ 50,000$ ),

- Higher for never-married than for married people and higher for married people than among those widowed or divorced,

- Higher for other races than for non-Hispanic whites, higher for non-Hispanic whites than for Hispanics, and higher for Hispanics than for blacks,

- Higher for college graduates than for those with some college and higher for those with some college than among high school graduates and dropouts, and

- Higher for those with more earnings.

\footnotetext{
${ }^{7}$ In this final model, we use a categorical specification for earnings. Model tests showed that this specification offered a better model fit than the continuous specification of earnings (both with and without a log transformation). Exploratory analyses showed that the relationship between earnings and the probability of contributing the maximum is not linear. Prior to 2002, when the percent of compensation ma ximum for $401 \mathrm{k}$ contributions was raised to 100 percent of annual salary, low earners were more likely to contribute the maximum than middle range earners because the ceiling set by the percent of compensation maximum was relatively low for the lowest earners.
} 
Table 4. Logit Regressions for Whether Individuals Contributing to 401k Plan Contribute Statutory Maximum or 10 Percent of Earnings

\begin{tabular}{|c|c|c|c|c|c|c|c|c|}
\hline \multirow[b]{3}{*}{ Independent Variables } & \multicolumn{2}{|c|}{ Model 1a } & \multirow{2}{*}{\multicolumn{2}{|c|}{$\begin{array}{c}\text { Model 2a } \\
\begin{array}{c}\text { Contribute } 10 \text { Percent } \\
\text { or Max }\end{array}\end{array}$}} & \multicolumn{2}{|c|}{ Model 1b } & \multirow{2}{*}{\multicolumn{2}{|c|}{$\begin{array}{c}\text { Model 2b } \\
\begin{array}{c}\text { Contribute } 10 \text { Percent } \\
\text { or Max }\end{array}\end{array}$}} \\
\hline & \multicolumn{2}{|c|}{ Contribute the Max } & & & \multicolumn{2}{|c|}{ Contribute the Max } & & \\
\hline & Coeff & Std Err & Coeff & Std Err & Coeff & Std Err & Coeff & Std Err \\
\hline \multicolumn{9}{|l|}{ Demographic Variables } \\
\hline Widowed or Divorced & \multicolumn{8}{|c|}{ (reference category) } \\
\hline Married & $0.310 * * *$ & 0.099 & $0.394 * * *$ & 0.054 & $0.308 * * *$ & 0.098 & $0.394 * * *$ & 0.054 \\
\hline Single & $0.660 * * *$ & 0.128 & $0.505 * * *$ & 0.071 & $0.644 * * *$ & 0.128 & $0.502 * * *$ & 0.071 \\
\hline Non-Hispanic White & \multicolumn{8}{|c|}{ (reference category) } \\
\hline Non-Hispanic Black & $-0.573 * * *$ & 0.185 & $-0.793 * * *$ & 0.088 & $-0.568 * * *$ & 0.185 & $-0.792 * * *$ & 0.088 \\
\hline Hispanic & -0.261 & 0.195 & $-0.374 * * *$ & 0.093 & -0.263 & 0.195 & $-0.374 * * *$ & 0.093 \\
\hline Non-Hispanic Other & $0.351 * * *$ & 0.130 & $0.304 * * *$ & 0.080 & $0.354 * * *$ & 0.129 & $0.305 * * *$ & 0.080 \\
\hline Age $<30$ & \multicolumn{8}{|c|}{ (reference category) } \\
\hline Age 30-34 & $0.581 * * *$ & 0.132 & $0.295 * * *$ & 0.057 & $0.563 * * *$ & 0.132 & $0.293 * * *$ & 0.057 \\
\hline Age 35-39 & $0.691 * * *$ & 0.142 & $0.456 * * *$ & 0.064 & $0.672 * * *$ & 0.141 & $0.455 * * *$ & 0.064 \\
\hline Age 40-44 & $0.740 * * *$ & 0.142 & $0.599 * * *$ & 0.065 & $0.715 * * *$ & 0.142 & $0.597 * * *$ & 0.065 \\
\hline Age 45-49 & $1.004 * * *$ & 0.144 & $0.804 * * *$ & 0.066 & $0.979 * * *$ & 0.144 & $0.802 * * *$ & 0.066 \\
\hline Age 50-54 & $1.234 * * *$ & 0.146 & $1.163 * * *$ & 0.067 & $1.207 * * *$ & 0.146 & $1.162 * * *$ & 0.067 \\
\hline Age 55-59 & $1.382 * * *$ & 0.152 & $1.479 * * *$ & 0.070 & $1.353 * * *$ & 0.152 & $1.476 * * *$ & 0.071 \\
\hline Age 60-64 & $1.861 * * *$ & 0.164 & $1.882 * * *$ & 0.079 & $1.829 * * *$ & 0.163 & $1.880 * * *$ & 0.079 \\
\hline Age 65-69 & $2.021 * * *$ & 0.226 & $2.093 * * *$ & 0.112 & $1.980 * * *$ & 0.226 & $2.088 * * *$ & 0.112 \\
\hline \multicolumn{9}{|l|}{ Education and Job Characteristics } \\
\hline High School Graduate or Less & \multicolumn{8}{|c|}{ (reference category) } \\
\hline Some College & $0.338 * * *$ & 0.122 & $0.338 * * *$ & 0.122 & $0.333 * * *$ & 0.121 & $0.173 * * *$ & 0.051 \\
\hline College Or more & $0.772 * * *$ & 0.117 & $0.772 * * *$ & 0.117 & $0.762 * * *$ & 0.116 & $0.547 * * *$ & 0.051 \\
\hline Self Employed & -0.133 & 0.102 & $0.207 * * *$ & 0.067 & -0.138 & 0.102 & $0.206 * * *$ & 0.067 \\
\hline Job Change This Year & $-0.410 * * *$ & 0.049 & $-0.502 * * *$ & 0.027 & $-0.389 * * *$ & 0.049 & $-0.498 * * *$ & 0.027 \\
\hline Years Contribute to 401K (1990-2003) & 0.011 & 0.009 & $0.050 * * *$ & 0.005 & 0.012 & 0.009 & $0.050 * * *$ & 0.005 \\
\hline \multicolumn{9}{|l|}{ Earnings and Earnings*Sex Interactions } \\
\hline Male Earnings $<25,000$ & \multicolumn{8}{|c|}{ (reference category) } \\
\hline Male Earnings 25,000-49,999 & $-1.336 * * *$ & 0.479 & 0.074 & 0.131 & $-1.328 * * *$ & 0.474 & 0.075 & 0.130 \\
\hline Male Earnings 50,000-74,999 & 0.157 & 0.457 & $0.452 * * *$ & 0.135 & 0.190 & 0.450 & $0.454 * * *$ & 0.134 \\
\hline Male Earnings 75,000-99,999 & $1.335 * * *$ & 0.449 & 0.247 & 0.154 & $1.391 * * *$ & 0.443 & 0.252 & 0.153 \\
\hline Male Earnings 100,000-124,999 & $2.089 * * *$ & 0.459 & 0.093 & 0.188 & $2.152 * * *$ & 0.453 & 0.102 & 0.187 \\
\hline Male Earnings 125,000 - 149,999 & $2.588 * * *$ & 0.474 & $0.590 * * *$ & 0.226 & $2.651 * * *$ & 0.468 & $0.598 * * *$ & 0.225 \\
\hline Male Earnings $>=150,000$ & $3.656 * * *$ & 0.459 & $1.654 * * *$ & 0.194 & $3.699 * * *$ & 0.454 & $1.658 * * *$ & 0.194 \\
\hline Female Earnings $<25,000$ & -0.161 & 0.332 & $0.315 * * *$ & 0.093 & -0.165 & 0.332 & $0.314 * * *$ & 0.093 \\
\hline Female Earnings 25,000-49,999 & -0.346 & 0.490 & $0.295 * *$ & 0.133 & -0.337 & 0.484 & $0.296 * *$ & 0.132 \\
\hline Female Earnings 50,000-74,999 & 0.639 & 0.462 & $0.724 * * *$ & 0.140 & 0.672 & 0.456 & $0.725 * * *$ & 0.140 \\
\hline Female Earnings 75,000-99,999 & $1.790 * * *$ & 0.460 & $0.675 * * *$ & 0.171 & $1.849 * * *$ & 0.454 & $0.680 * * *$ & 0.170 \\
\hline Female Earnings 100,000-124,999 & $2.491 * * *$ & 0.472 & $0.517 * *$ & 0.224 & $2.545 * * *$ & 0.466 & $0.524 * *$ & 0.223 \\
\hline Female Earnings 125,000 - 149,999 & $3.179 * * *$ & 0.496 & $1.318 * * *$ & 0.270 & $3.243 * * *$ & 0.490 & $1.327 * * *$ & 0.269 \\
\hline Female Earnings $>=150,000$ & $4.074 * * *$ & 0.483 & $2.237 * * *$ & 0.251 & $4.116 * * *$ & 0.479 & $2.242 * * *$ & 0.251 \\
\hline * Significant at .10 level & & & & & & & Continued & \\
\hline ** Significant at .05 level & & & & & & & & \\
\hline
\end{tabular}


Table 4. Logit Regressions for Whether Individuals Contributing to 401k Plan Contribute Statutory Maximum or 10 Percent of Earnings (Continued)

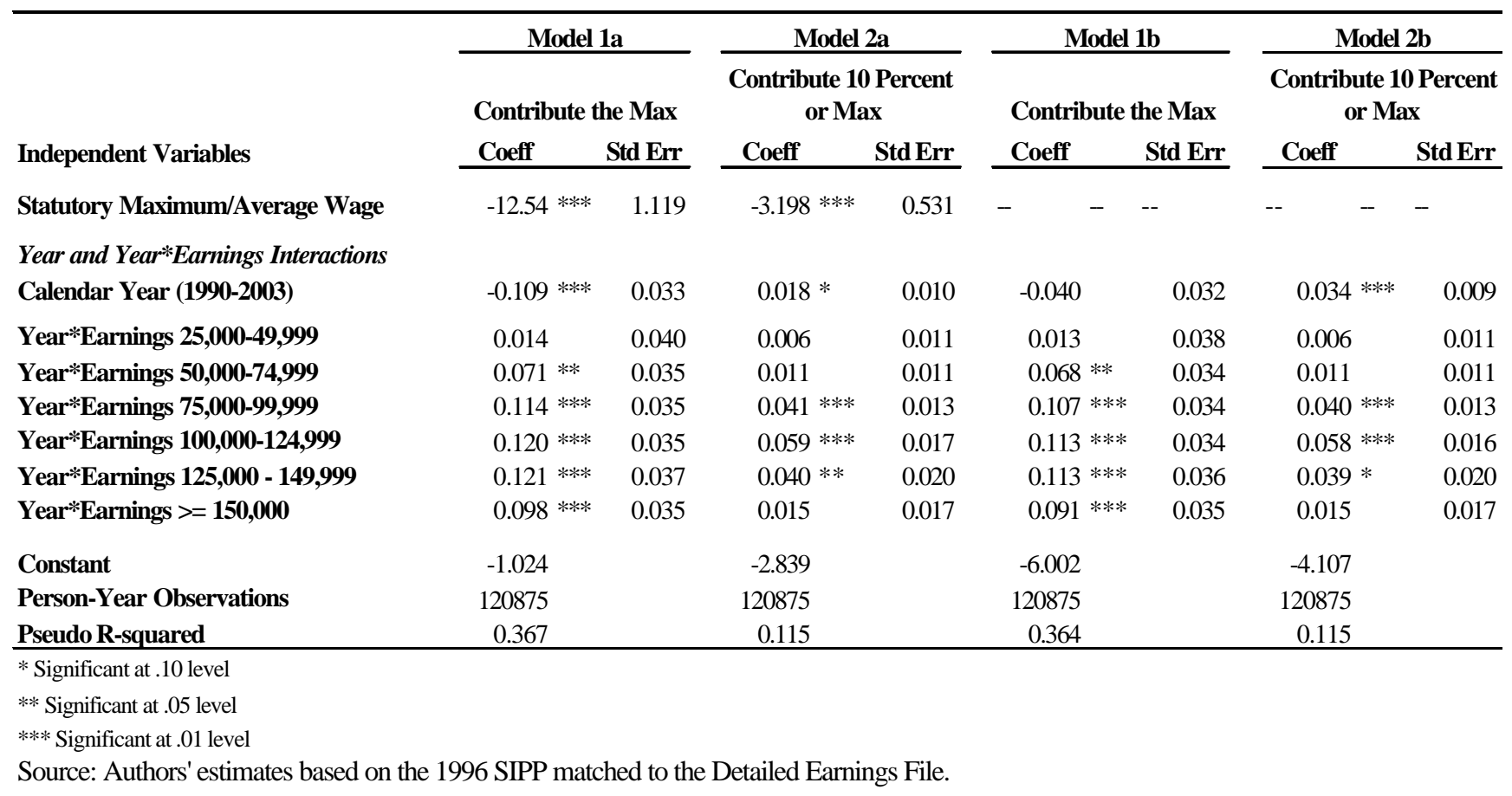

While self-employment income does not have a significant effect on the probability of contributing the maximum, its effect on the probability of being a large contributor is positive and significant.

We use a series of combined gender-earnings dummies in the model to capture the complex relationship between gender, earnings and the likelihood of contributing the maximum. The reference category for these gender-earnings groups is males with annual earnings of less than $\$ 25,000$. Both the male and female earnings dummies again indicate a bimodal relationship between earnings and contributing the maximum. The probability of contributing the maximum relative to the lowest earnings group $(<\$ 25,000)$ first drops for individuals earning $\$ 25,000-\$ 49,999$, but thereafter increases monotonically with earnings level. The probability of being a large contributor, however, increases monotonically with earnings. At all earnings levels over $\$ 25,000$, females are more likely to be large contributors and maximum contributors than males.

We include controls for plan contribution history, measured as the number of years the person contributed to a tax-deferred retirement plan between1990 and 2003, and whether or not he or she experienced a job change in the current year. We would expect that individuals who are regular contributors are more likely to be large contributors; the results confirm this expectation, but frequent contributors do not appear more likely to be maximum contributors. People who have recently experienced a job change in the current year are less likely to be both large contributors and maximum contributors, possibly because their potential contributions were limited in the first year on a new job. 
When we include the ratio of the statutory maximum individual contribution to the average wage as an explanatory variable (Table 4, Models 1a and 2a), we find that raising the statutory maximum reduces the shares of both maximum contributors and large contributors. The former would be expected, as a higher maximum amount in relation to the average wage means that, at any given percentage of wages contributed, an individual is less likely to be at the statutory dollar limit. Raising the statutory maximum, however, also moves some employees out of the "large contributor" group. For high-earning individuals for whom the statutory maximum is less than 10 percent of wages, a higher maximum raises the share of wages they must set aside to be classified as a large contributor.

The calendar year term and the interaction terms between calendar year and earnings indicate how much shares of maximum contributors and large contributors have increased over time, controlling for other factors that influence shares of maximum and large contributors. The coefficients of the calendar year term in Models $2 \mathrm{a}$ and $2 \mathrm{~b}$ show that the share of large contributors for the lowest earnings group has been increasing over time. For maximum contributors, ho wever, the time trend variable is small and not statistically different when not controlling for changes in the relative (to wages) dollar contribution limit and negative when the dollar contribution limit term is included in the equation (Model 1a). This result implies that, if the dollar contribution limit had remained a fixed share of the average wage, the share of low earners who contribute the maximum would have decreased over the period. Note that the coefficient on the calendar year term is smaller (i.e., more negative or less positive) in equations where the dollar contribution limit is included. In effect, the decline over the period in the relative contribution limit would by itself have contributed to an increase in the share of maximum and large contributors over time, so including the contribution limit variable in the equation makes the time trend effect less positive for large contributors, and more negative for maximum contributors.

The year-earnings interaction terms (bottom rows of Table 4) indicate that the shares of both maximum and large contributors generally increased more for higher than for lower earning groups, when controlling for other influences on the share of maximum and large contributors. For shares of maximum contributors, the highest growth rates were for workers with earnings between $\$ 75,000$ and $\$ 150,000$. For shares of large contributors, the highest growth rates were for workers with earnings between $\$ 75,000$ and $\$ 125,000$.

\section{CONCLUSIONS}

Total participation in and contributions to employer-sponsored tax-deferred retirement accounts has increased strongly since 1990. These tax-deferred retirement accounts are gradually replacing defined benefit plans as the primary form of employer-provided pension coverage. Tax law changes since 2001 have increased the maximum amounts employees may contribute to these accounts and also permitted additional "catch-up contributions" for workers over age 50.

Most employees do not contribute the maximum allowable amount to tax-deferred retirement amounts, but the share of workers who do contribute the maximum differs across economic and demographic groups. The probability of contributing the maximum varies positively 
with age, earnings, level of education, and presence of some self-employment income and is higher for Non-Hispanic whites and others than for Hispanics and non-Hispanic blacks and higher for never-married and married workers than for those who are divorced or widowed.

The maximum amount workers can contribute to tax-deferred accounts has increased over time, but decreased as a share of the average wage over the 1990-2001 period and was still lower in 2003 than it had been in 1990 for workers under age 50. Absent other changes, we estimate that the decline in the maximum dollar amount relative to wages would have increased the share of workers who contribute the maximum. The percentage of workers who contribute the maximum did increase between 1990 and 2003, but the increase was concentrated among groups who already had high contribution rates in 1990. The growth in the shares of workers who contribute the maximum amount was much greater for high than for low-earning workers, for more than for less-educated workers, and for whites than for Hispanics and blacks. Between 1990 and 2003, there was no growth in the share of low-earning workers who contribute the maximum amount.

Higher earning workers, more educated workers, and whites are also more likely to be large contributors than lower earning and less educated workers and minorities, where large contributors are defined as those who contribute either 10 percent or earnings or the legal maximum. But differences in shares of large contributors by earnings, education, and race are narrower than differences in shares of maximum contributors by these characteristics. In addition, while the share of large contributors has increased faster for higher earning workers than for lower earning workers, the share of large contributors has increased between 1990 and 2003 for all earnings and demographic groups.

The maximum dollar amount workers may contribute to tax-deferred accounts has increased sharply since 2001, both in absolute terms and in relation to average earnings, and the growth has been especially large for workers over 50 who may make additional "catch-up" contributions that will amount to $\$ 5,000$ by tax year 2006 . The analysis in this paper suggests that these changes will reduce the share of people who take full advantage of the tax preference and could further the trends towards raising the relative shares of large or maximum contributors among groups who already are large or maximum contributors. 


\section{References}

Andrews, Emily S. (1992). "The Growth and Distribution of 401(k) Plans.” In Trends in Pensions, edited by John A. Turner and Daniel J. Beller, 149-176. Washington, D.C.: United States Department of Labor, Pension and Welfare Benefits Administration.

Bassett, William F., Michael J. Fleming, and Anthony P. Rodrigues (1998). "How Workers Use 401(k) Plans: The Participation, Contribution, and Withdrawal Decisions." National Tax Journal 51 No. 2 (July, 1998): 263-89.

Benartzi, Schomo and Richard Thaler (2004). "Save More Tomorrow: Using Behavioral Economics to Increase Employee Saving." Journal of Political Economy 112-1, S164-S187. February.

Choi, James J., David Laibson, Brigitte C. Madrian, and Andrew Metrick (2002). "Defined Contribution Pensions: Plan Rules, Participant Choices, and the Path of Least Resistance." In Tax Policy and the Economy, edited by James M. Poterba. Cambridge, Ma.: MIT Press.

Choi, James, J., David Laibson and Brigitte C. Madrian (2004a). "Plan Design and 401K Savings Outcomes." National Tax Journal 57, June 2004 pp. 275-298

Choi, James, J., David Laibson, Brigitte Madrian and Andrew Metrick (2004b). "For Better or For Worse: Default Effects and 401(k) Savings Behavior" in Perspectives in the Economics of Aging edited by David Wise. Chicago, IL: University of Chicago Press.

Choi, James J., David Laibson, Brigette C. Madrian, and Andrew Metrick (2004c). "Saving For Retirement on the Path of Least Resistance." Working Paper. UCLA Department of Economics. July 19.

Clark, Robert L., Gordon P. Goodfellow, Sylvester J. Schieber, and Drew Warwick. (2000). "Making the Most of 401(k) Plans: Who’s Choosing What and Why?" In Forecasting Retirement Needs and Retirement Wealth, edited by Olivia S. Mitchell, P. Brett Hammond, and Anna M. Rappaport, 95-138. Philadelphia, Pennsylvania: Pension Research Council, the Wharton School of the University of Pennsylvania, and the University of Pennsylvania Press.

Clark, Robert L., and Sylvester J. Schieber. (1998). "Factors Affecting Participation Rates and Contribution Levels in 401(k) Plans." In Living with Defined Contribution Pensions: Remaking Responsibility for Retirement, edited by Olivia S. Mitchell and Sylvester J. Schieber, 69-97. Philadelphia, Pennsylvania: Pension Research Council, the Wharton School of the University of Pennsylvania, and the University of Pennsylvania Press.

Congressional Budget Office (2003). "Utilization of Tax Incentives for Retirement Saving.” Report (August 2003).

Cunninghan, Cristopher R. and Gary V. Engelhardt. (2002). "Federal Tax Policy, Employer Matching, and 401(k) Saving: Evidence from HRS W-2 Records." National Tax Journal 55, No. 3 (September): 617-645. 
Engelhardt, Gary V. and Anil Kumar. (2003). "Employer Matching and 401(k) Saving: Evidence from the Health and Retirement Study." Syracuse University Working Paper. Syracuse, NY: Syracuse University.

Even, William E., and David A. Macpherson. (1997) "Factors Influencing Participation and Contribution Levels in 401(k) Plans." Florida State University Working Paper. Tallahassee, FL: Florida State University.

General Accounting Office (2001). "Issues of Coverage and Increasing Contribution Limits for Defined Contribution Plans." Report to the Ranking Minority Member, Subcommittee on Oversight, Committee on Ways and Means, House of Representatives.

General Accounting Office (1997). “401K Pension Plans: Loan Provisions Enhance Participation, but May Affect Retirement Security for Some.” GAO/HEHS-98-5. October.

Holden, Sarah and Jack VanDerhei (2001). "Contribution Behavior of 401(k) Plan Participants." Perspective 7 No. 4 (October): 1-19.

Huberman, Gur, Sheena Iyengar, and Wei Jiang (2003). "Defined Contribution Pension Plans: Determinants of Participation and Contribution Rates." Columbia University Working Paper. New York, NY: Columbia University.

Investment Company Institute (2000). “401(k) Plan Participants: Characteristics, Contributions and Account Activity” Paper for the ICI Research Series (Spring 2000).

Joulfaian, David, and David Richardson. (2001). "Who Takes Advantage of Tax-Deferred Savings Programs? Evidence from Federal Income Tax Data." National Tax Journal 54 No. 3

(September): 669-688.

Kusko, Andrea L.; James M. Poterba; and David W. Wilcox (1998). "Employee Decisions with Respect to 401(k) Plans." In Living with Defined Contribution Pensions: Remaking Responsibility for Retirement, edited by Olivia S. Mitchell and Sylvester J. Schieber 98-112. Philadelphia, Pennsylvania: Pension Research Council, the Wharton School of the University of Pennsylvania, and the University of Pennsylvania Press.

Madrian, Brigitte C. and Dennis F. Shea (2001). "The Power of Suggestion: Inertia in 401(k) Participation and Savings Behavior." Quarterly Journal of Economics 116 No. 4 (November): 1149-1525.

Munnell, Alicia H., and Annika Sundén (2004). Coming Up Short: The Challenge of 401(k) Plans. Washington, D.C.: Brookings Institution Press.

Munnell, Alicia H., Annika Sundén, and Catherine Taylor (2003). "What Determines 401(k) Participation and Contributions?” Social Security Bulletin 64 No. 3 (January): 64-75. 
Orszag, Peter (2005). "Social Security Reform" Testimony before the Senate Committee on Finance, April 26, 2005. Available online at: http://apps49.brookings.edu/dybdocroot/views/testimony/orszag/20050426.pdf

Papke, Leslie E. (1992). "Participation in and Contributions to 401(k) Pension Plans: Evidence from Plan Data." Journal of Human Resources 30 No. 2 (Spring): 311-325.

Papke, Leslie E. and James M Poterba (1995). "Survey Evidence on Employer Match Rates and Employee Saving Behavior in 401k Plans." Economics Letters 49: 313-317.

Papke, Leslie E., Mitchell Peterson, and James M. Poterba (1996). "Do 401(k) Plans Replace Other Employer-Provided Pensions?" In Advances in the Economics of Aging, edited by David A. Wise, 219-236. Chicago: University of Chicago Press.

Papke, Leslie E. (2004). "Individual Financial Decisions in Retireme nt Saving Plans: The Role of Participant-Direction.” Journal of Public Economics 88 Nos. 1-2 (January): 39-61.

President's Advisory Plane on Federal Tax Reform (2005). Simple, Fair and Pro-Growth: Proposals to Fix America's Tax System. November 2005.

Smith, Karen E., Richard W. Johnson, and Leslie A. Muller (2004). "Deferring Income in Employer-Sponsored Retirement Plans: The Dynamics of Participant Contributions." Report prepared for Center for Retirement Research at Boston College. September. 


\section{Appendix}

The appendix includes some additional background data. Table A1 shows the percentage of participants who were maximum contributors for every year between 1990 and 2003, broken down by earnings, sex, marital status, self-employment status, education, race and age. These are the data behind Figures 1 through 11 in the text. Table A2 shows the same data for those participants who contributed either 10 percent of earnings or the dollar maximum between 1990 and 2003. Tables A3 and A4 provide predicted probabilities of contributing the maximum or large contributions from Models 1a and 2a in Table 4. 
Table A1. Percent of Participants Contributing the Statutory Maximum to Their Tax-Deferred Retirement Plans by Select Characteristics (1990 2003)

\begin{tabular}{|c|c|c|c|c|c|c|c|c|c|c|c|c|c|c|}
\hline & \multicolumn{14}{|c|}{ Year } \\
\hline & 1990 & 1991 & 1992 & 1993 & 1994 & 1995 & 1996 & 1997 & 1998 & 1999 & 2000 & 2001 & 2002 & 2003 \\
\hline All & $3.5 \%$ & $3.3 \%$ & $3.5 \%$ & $3.9 \%$ & $3.6 \%$ & $4.1 \%$ & $4.2 \%$ & $5.4 \%$ & $5.2 \%$ & $6.6 \%$ & $6.8 \%$ & $7.5 \%$ & $6.4 \%$ & $6.0 \%$ \\
\hline \multicolumn{15}{|l|}{ Total Earnings } \\
\hline $0<-10000$ & $1.7 \%$ & $0.0 \%$ & $0.9 \%$ & $0.8 \%$ & $0.7 \%$ & $0.0 \%$ & $2.2 \%$ & $3.9 \%$ & $1.4 \%$ & $1.5 \%$ & $2.0 \%$ & $2.5 \%$ & $1.8 \%$ & $1.2 \%$ \\
\hline $10000-25000$ & $0.7 \%$ & $0.8 \%$ & $1.0 \%$ & $1.0 \%$ & $0.6 \%$ & $0.7 \%$ & $0.6 \%$ & $0.8 \%$ & $0.3 \%$ & $0.4 \%$ & $0.4 \%$ & $0.7 \%$ & $0.2 \%$ & $0.3 \%$ \\
\hline $25000-50000$ & $0.9 \%$ & $0.7 \%$ & $0.5 \%$ & $0.6 \%$ & $0.5 \%$ & $0.4 \%$ & $0.4 \%$ & $0.4 \%$ & $0.3 \%$ & $0.4 \%$ & $0.5 \%$ & $0.6 \%$ & $0.6 \%$ & $0.5 \%$ \\
\hline $50000-75000$ & $2.5 \%$ & $2.4 \%$ & $2.1 \%$ & $2.1 \%$ & $2.2 \%$ & $2.2 \%$ & $2.6 \%$ & $2.7 \%$ & $2.5 \%$ & $3.7 \%$ & $3.1 \%$ & $3.9 \%$ & $3.0 \%$ & $2.4 \%$ \\
\hline $75000-100000$ & $5.9 \%$ & $7.1 \%$ & $6.9 \%$ & $10.0 \%$ & $7.5 \%$ & $10.8 \%$ & $9.3 \%$ & $14.5 \%$ & $13.0 \%$ & $15.5 \%$ & $15.3 \%$ & $16.4 \%$ & $15.2 \%$ & $12.2 \%$ \\
\hline 100000-130000 & $16.7 \%$ & $9.2 \%$ & $15.7 \%$ & $15.8 \%$ & $17.6 \%$ & $20.7 \%$ & $22.8 \%$ & $28.8 \%$ & $25.0 \%$ & $32.6 \%$ & $33.4 \%$ & $34.4 \%$ & $25.9 \%$ & $26.0 \%$ \\
\hline 130000-150000 & $23.3 \%$ & $29.2 \%$ & $21.7 \%$ & $25.7 \%$ & $30.1 \%$ & $34.4 \%$ & $37.5 \%$ & $35.7 \%$ & $39.4 \%$ & $44.2 \%$ & $38.8 \%$ & $52.5 \%$ & $41.9 \%$ & $37.8 \%$ \\
\hline $150000+$ & $46.8 \%$ & $45.2 \%$ & $48.2 \%$ & $48.9 \%$ & $47.0 \%$ & $46.2 \%$ & $45.9 \%$ & $56.8 \%$ & $51.7 \%$ & $60.5 \%$ & $61.6 \%$ & $65.7 \%$ & $57.2 \%$ & $53.2 \%$ \\
\hline \multicolumn{15}{|l|}{ Sex } \\
\hline Male & $4.1 \%$ & $3.8 \%$ & $4.3 \%$ & $4.9 \%$ & $4.8 \%$ & $5.4 \%$ & $5.6 \%$ & $7.2 \%$ & $7.2 \%$ & $9.0 \%$ & $9.1 \%$ & $9.9 \%$ & $8.1 \%$ & $8.0 \%$ \\
\hline Female & $2.8 \%$ & $2.6 \%$ & $2.4 \%$ & $2.7 \%$ & $2.3 \%$ & $2.4 \%$ & $2.4 \%$ & $3.1 \%$ & $2.7 \%$ & $3.8 \%$ & $4.1 \%$ & $4.6 \%$ & $4.4 \%$ & $3.6 \%$ \\
\hline \multicolumn{15}{|l|}{ Marital Status } \\
\hline Never Married & $1.7 \%$ & $2.3 \%$ & $2.3 \%$ & $2.2 \%$ & $2.3 \%$ & $2.5 \%$ & $2.7 \%$ & $3.4 \%$ & $3.6 \%$ & $3.8 \%$ & $4.1 \%$ & $4.4 \%$ & $4.4 \%$ & $3.9 \%$ \\
\hline Married & $4.0 \%$ & $3.8 \%$ & $4.0 \%$ & $4.6 \%$ & $4.0 \%$ & $4.6 \%$ & $4.8 \%$ & $6.3 \%$ & $6.0 \%$ & $7.7 \%$ & $8.0 \%$ & $8.9 \%$ & $7.5 \%$ & $7.1 \%$ \\
\hline Widowed & $4.9 \%$ & $2.0 \%$ & $0.0 \%$ & $2.2 \%$ & $2.7 \%$ & $2.1 \%$ & $1.2 \%$ & $2.8 \%$ & $3.1 \%$ & $3.4 \%$ & $4.1 \%$ & $3.0 \%$ & $3.5 \%$ & $1.9 \%$ \\
\hline Divorced & $3.0 \%$ & $1.9 \%$ & $2.3 \%$ & $2.4 \%$ & $3.3 \%$ & $2.9 \%$ & $2.5 \%$ & $3.1 \%$ & $2.6 \%$ & $4.5 \%$ & $4.3 \%$ & $4.7 \%$ & $3.8 \%$ & $3.9 \%$ \\
\hline \multicolumn{15}{|l|}{ Self-Employed } \\
\hline No & $3.5 \%$ & $3.3 \%$ & $3.4 \%$ & $3.9 \%$ & $3.5 \%$ & $3.8 \%$ & $4.0 \%$ & $5.1 \%$ & $5.0 \%$ & $6.3 \%$ & $6.6 \%$ & $7.3 \%$ & $6.2 \%$ & $5.7 \%$ \\
\hline Yes & $3.8 \%$ & $4.5 \%$ & $5.7 \%$ & $3.7 \%$ & $8.2 \%$ & $9.3 \%$ & $8.9 \%$ & $12.7 \%$ & $10.4 \%$ & $13.9 \%$ & $12.2 \%$ & $11.9 \%$ & $11.7 \%$ & $11.8 \%$ \\
\hline \multicolumn{15}{|l|}{ Education } \\
\hline Less than High School & $0.7 \%$ & $0.5 \%$ & $0.5 \%$ & $0.5 \%$ & $0.5 \%$ & $0.4 \%$ & $0.8 \%$ & $1.4 \%$ & $0.7 \%$ & $0.8 \%$ & $1.0 \%$ & $1.1 \%$ & $0.6 \%$ & $0.8 \%$ \\
\hline High School Graduate & $1.1 \%$ & $0.7 \%$ & $0.7 \%$ & $0.6 \%$ & $0.6 \%$ & $0.9 \%$ & $1.0 \%$ & $1.5 \%$ & $1.2 \%$ & $2.0 \%$ & $2.0 \%$ & $1.8 \%$ & $1.7 \%$ & $1.5 \%$ \\
\hline Some College/Assoc/Voc & $2.3 \%$ & $2.0 \%$ & $1.7 \%$ & $2.1 \%$ & $2.3 \%$ & $2.3 \%$ & $2.1 \%$ & $2.7 \%$ & $2.4 \%$ & $2.9 \%$ & $3.2 \%$ & $3.8 \%$ & $2.7 \%$ & $2.5 \%$ \\
\hline College Graduate Plus & $6.0 \%$ & $6.0 \%$ & $6.7 \%$ & $7.6 \%$ & $6.8 \%$ & $7.8 \%$ & $8.1 \%$ & $10.2 \%$ & $10.2 \%$ & $13.1 \%$ & $13.5 \%$ & $15.0 \%$ & $13.3 \%$ & $12.4 \%$ \\
\hline \multicolumn{15}{|l|}{ Race } \\
\hline Non-Hispanic White & $3.6 \%$ & $3.4 \%$ & $3.7 \%$ & $4.1 \%$ & $3.9 \%$ & $4.4 \%$ & $4.6 \%$ & $5.9 \%$ & $5.7 \%$ & $7.2 \%$ & $7.4 \%$ & $8.0 \%$ & $7.0 \%$ & $6.6 \%$ \\
\hline Non-Hispanic Black & $1.5 \%$ & $1.3 \%$ & $1.1 \%$ & $1.6 \%$ & $1.8 \%$ & $1.6 \%$ & $1.4 \%$ & $2.4 \%$ & $2.0 \%$ & $2.8 \%$ & $2.2 \%$ & $3.1 \%$ & $1.8 \%$ & $2.1 \%$ \\
\hline Hispanic & $3.8 \%$ & $2.9 \%$ & $2.9 \%$ & $2.6 \%$ & $1.2 \%$ & $1.9 \%$ & $1.4 \%$ & $2.8 \%$ & $2.2 \%$ & $2.2 \%$ & $2.7 \%$ & $3.4 \%$ & $3.2 \%$ & $2.3 \%$ \\
\hline Other & $5.7 \%$ & $4.9 \%$ & $4.9 \%$ & $6.3 \%$ & $4.8 \%$ & $5.3 \%$ & $3.9 \%$ & $5.0 \%$ & $5.2 \%$ & $10.5 \%$ & $11.8 \%$ & $12.6 \%$ & $10.3 \%$ & $9.9 \%$ \\
\hline \multicolumn{15}{|l|}{ Age } \\
\hline $20-29$ & $0.0 \%$ & $0.3 \%$ & $0.3 \%$ & $0.2 \%$ & $0.4 \%$ & $0.4 \%$ & $0.6 \%$ & $0.9 \%$ & $0.8 \%$ & $1.2 \%$ & $1.2 \%$ & $2.0 \%$ & $1.6 \%$ & $1.4 \%$ \\
\hline 30-39 & $1.5 \%$ & $1.6 \%$ & $1.4 \%$ & $1.7 \%$ & $1.5 \%$ & $1.9 \%$ & $2.6 \%$ & $3.7 \%$ & $3.9 \%$ & $5.8 \%$ & $5.8 \%$ & $6.1 \%$ & $6.6 \%$ & $5.6 \%$ \\
\hline $40-49$ & $3.4 \%$ & $3.2 \%$ & $3.8 \%$ & $4.7 \%$ & $4.6 \%$ & $5.2 \%$ & $4.6 \%$ & $5.5 \%$ & $5.7 \%$ & $7.0 \%$ & $7.2 \%$ & $7.6 \%$ & $7.7 \%$ & $7.4 \%$ \\
\hline $50-59$ & $8.5 \%$ & $6.9 \%$ & $7.5 \%$ & $7.9 \%$ & $6.9 \%$ & $7.7 \%$ & $7.7 \%$ & $9.4 \%$ & $8.2 \%$ & $9.7 \%$ & $9.9 \%$ & $10.8 \%$ & $6.8 \%$ & $6.8 \%$ \\
\hline $60-65$ & $10.8 \%$ & $11.5 \%$ & $10.9 \%$ & $10.5 \%$ & $10.0 \%$ & $7.2 \%$ & $8.2 \%$ & $11.9 \%$ & $8.7 \%$ & $9.5 \%$ & $11.1 \%$ & $13.0 \%$ & $7.0 \%$ & $6.0 \%$ \\
\hline $66+$ & $10.7 \%$ & $14.4 \%$ & $10.4 \%$ & $13.3 \%$ & $8.2 \%$ & $10.0 \%$ & $5.2 \%$ & $12.8 \%$ & $14.0 \%$ & $7.7 \%$ & $3.0 \%$ & $7.5 \%$ & $6.4 \%$ & $6.1 \%$ \\
\hline
\end{tabular}

Source: Authors' calculations based on the 1996 SIPP matched to the Detailed Earnings File. 
Table A2. Percent of Participants Contributing 10\% or More of Total Annual Earnings OR the Statutory Maximum to Tax-Deferred Retirement Plan by Select Characteristics (1990 - 2003)

\begin{tabular}{|c|c|c|c|c|c|c|c|c|c|c|c|c|c|c|}
\hline & \multicolumn{14}{|c|}{ Year } \\
\hline & 1990 & 1991 & 1992 & 1993 & 1994 & 1995 & 1996 & 1997 & 1998 & 1999 & 2000 & 2001 & 2002 & 2003 \\
\hline All & $13.6 \%$ & $13.1 \%$ & $13.7 \%$ & $15.0 \%$ & $15.8 \%$ & $16.1 \%$ & $17.0 \%$ & $18.3 \%$ & $18.8 \%$ & $19.7 \%$ & $20.6 \%$ & $22.0 \%$ & $21.4 \%$ & $21.6 \%$ \\
\hline \multicolumn{15}{|l|}{ Total Earnings } \\
\hline $0<-10000$ & $11.2 \%$ & $10.5 \%$ & $10.0 \%$ & $12.3 \%$ & $10.2 \%$ & $13.1 \%$ & $16.9 \%$ & $13.3 \%$ & $10.0 \%$ & $13.4 \%$ & $16.5 \%$ & $13.5 \%$ & $17.3 \%$ & $22.2 \%$ \\
\hline $10000-25000$ & $9.6 \%$ & $8.6 \%$ & $10.9 \%$ & $9.2 \%$ & $10.2 \%$ & $10.2 \%$ & $10.2 \%$ & $10.3 \%$ & $10.5 \%$ & $10.4 \%$ & $11.2 \%$ & $13.0 \%$ & $11.8 \%$ & $12.8 \%$ \\
\hline $25000-50000$ & $9.3 \%$ & $9.4 \%$ & $9.9 \%$ & $10.9 \%$ & $12.0 \%$ & $12.3 \%$ & $12.8 \%$ & $13.3 \%$ & $13.5 \%$ & $13.7 \%$ & $14.0 \%$ & $15.0 \%$ & $14.8 \%$ & $14.9 \%$ \\
\hline $50000-75000$ & $17.0 \%$ & $16.2 \%$ & $15.6 \%$ & $19.0 \%$ & $19.5 \%$ & $19.9 \%$ & $21.5 \%$ & $22.5 \%$ & $22.7 \%$ & $23.5 \%$ & $23.7 \%$ & $25.2 \%$ & $24.8 \%$ & $23.5 \%$ \\
\hline $75000-100000$ & $17.4 \%$ & $18.8 \%$ & $18.0 \%$ & $20.3 \%$ & $19.6 \%$ & $21.5 \%$ & $22.1 \%$ & $25.8 \%$ & $27.1 \%$ & $27.3 \%$ & $29.1 \%$ & $30.4 \%$ & $32.5 \%$ & $33.9 \%$ \\
\hline $100000-130000$ & $18.8 \%$ & $9.2 \%$ & $18.3 \%$ & $18.4 \%$ & $23.0 \%$ & $22.2 \%$ & $24.3 \%$ & $30.0 \%$ & $29.0 \%$ & $34.1 \%$ & $36.4 \%$ & $37.3 \%$ & $34.1 \%$ & $35.9 \%$ \\
\hline $130000-150000$ & $23.3 \%$ & $29.2 \%$ & $23.1 \%$ & $25.7 \%$ & $31.6 \%$ & $35.8 \%$ & $37.5 \%$ & $37.7 \%$ & $39.4 \%$ & $45.0 \%$ & $39.6 \%$ & $53.1 \%$ & $49.1 \%$ & $48.5 \%$ \\
\hline $150000+$ & $46.8 \%$ & $47.2 \%$ & $49.0 \%$ & $49.7 \%$ & $47.6 \%$ & $47.3 \%$ & $46.9 \%$ & $58.5 \%$ & $53.5 \%$ & $60.9 \%$ & $62.3 \%$ & $65.7 \%$ & $68.0 \%$ & $63.5 \%$ \\
\hline \multicolumn{15}{|l|}{ Marital Status } \\
\hline Never Married & $6.9 \%$ & $8.3 \%$ & $8.4 \%$ & $9.5 \%$ & $10.4 \%$ & $11.1 \%$ & $10.9 \%$ & $13.9 \%$ & $15.0 \%$ & $15.5 \%$ & $15.2 \%$ & $16.1 \%$ & $15.8 \%$ & $16.1 \%$ \\
\hline Married & $15.3 \%$ & $14.7 \%$ & $15.2 \%$ & $16.2 \%$ & $16.8 \%$ & $17.6 \%$ & $18.5 \%$ & $19.7 \%$ & $20.4 \%$ & $21.6 \%$ & $22.9 \%$ & $24.6 \%$ & $23.8 \%$ & $24.1 \%$ \\
\hline Widowed & $26.0 \%$ & $22.3 \%$ & $28.6 \%$ & $25.8 \%$ & $26.0 \%$ & $23.7 \%$ & $22.2 \%$ & $21.9 \%$ & $22.7 \%$ & $22.5 \%$ & $19.7 \%$ & $19.1 \%$ & $15.8 \%$ & $13.8 \%$ \\
\hline Divorced & $10.7 \%$ & $8.2 \%$ & $9.3 \%$ & $11.6 \%$ & $14.8 \%$ & $13.0 \%$ & $15.2 \%$ & $15.2 \%$ & $13.5 \%$ & $14.7 \%$ & $14.9 \%$ & $16.7 \%$ & $18.0 \%$ & $18.8 \%$ \\
\hline \multicolumn{15}{|l|}{ Self-Employment Status } \\
\hline No & $13.3 \%$ & $12.8 \%$ & $13.5 \%$ & $15.1 \%$ & $15.6 \%$ & $15.8 \%$ & $16.8 \%$ & $17.8 \%$ & $18.3 \%$ & $19.1 \%$ & $20.1 \%$ & $21.6 \%$ & $21.1 \%$ & $21.3 \%$ \\
\hline Yes & $22.4 \%$ & $21.8 \%$ & $17.7 \%$ & $13.8 \%$ & $21.0 \%$ & $22.6 \%$ & $21.8 \%$ & $29.1 \%$ & $28.9 \%$ & $32.8 \%$ & $30.0 \%$ & $29.2 \%$ & $27.6 \%$ & $28.7 \%$ \\
\hline \multicolumn{15}{|l|}{ Education } \\
\hline Less than High School & $5.2 \%$ & $6.2 \%$ & $7.9 \%$ & $9.7 \%$ & $9.1 \%$ & $8.7 \%$ & $9.3 \%$ & $9.2 \%$ & $9.4 \%$ & $7.5 \%$ & $10.4 \%$ & $10.8 \%$ & $11.6 \%$ & $11.4 \%$ \\
\hline High School Graduate & $10.9 \%$ & $9.5 \%$ & $10.5 \%$ & $11.2 \%$ & $11.7 \%$ & $11.6 \%$ & $13.4 \%$ & $13.5 \%$ & $13.9 \%$ & $14.4 \%$ & $15.1 \%$ & $15.5 \%$ & $14.5 \%$ & $14.6 \%$ \\
\hline Some College/Assoc/Voc & $11.9 \%$ & $12.3 \%$ & $12.1 \%$ & $12.7 \%$ & $13.4 \%$ & $13.5 \%$ & $14.2 \%$ & $14.8 \%$ & $14.9 \%$ & $15.2 \%$ & $15.7 \%$ & $17.1 \%$ & $16.4 \%$ & $17.1 \%$ \\
\hline College Graduate Plus & $17.1 \%$ & $16.3 \%$ & $17.2 \%$ & $19.5 \%$ & $20.6 \%$ & $21.9 \%$ & $22.1 \%$ & $24.8 \%$ & $25.6 \%$ & $28.0 \%$ & $29.1 \%$ & $31.5 \%$ & $31.3 \%$ & $31.0 \%$ \\
\hline \multicolumn{15}{|l|}{ Race } \\
\hline Non-Hispanic White & $14.1 \%$ & $13.8 \%$ & $14.5 \%$ & $15.9 \%$ & $16.7 \%$ & $17.3 \%$ & $18.4 \%$ & $19.6 \%$ & $20.4 \%$ & $21.3 \%$ & $22.2 \%$ & $23.5 \%$ & $22.8 \%$ & $23.4 \%$ \\
\hline Non-Hispanic Black & $8.5 \%$ & $7.0 \%$ & $6.5 \%$ & $6.8 \%$ & $7.0 \%$ & $6.9 \%$ & $6.6 \%$ & $8.4 \%$ & $8.3 \%$ & $8.4 \%$ & $8.3 \%$ & $12.4 \%$ & $11.9 \%$ & $10.4 \%$ \\
\hline Hispanic & $9.9 \%$ & $7.6 \%$ & $8.2 \%$ & $9.8 \%$ & $7.8 \%$ & $8.5 \%$ & $8.7 \%$ & $11.5 \%$ & $10.5 \%$ & $11.6 \%$ & $11.6 \%$ & $12.7 \%$ & $12.2 \%$ & $11.5 \%$ \\
\hline Other & $16.6 \%$ & $14.8 \%$ & $16.9 \%$ & $20.0 \%$ & $23.6 \%$ & $21.4 \%$ & $20.6 \%$ & $20.7 \%$ & $19.4 \%$ & $25.0 \%$ & $28.7 \%$ & $28.7 \%$ & $29.8 \%$ & $29.1 \%$ \\
\hline \multicolumn{15}{|l|}{ Age } \\
\hline $20-29$ & $4.3 \%$ & $3.7 \%$ & $4.1 \%$ & $3.7 \%$ & $6.1 \%$ & $5.8 \%$ & $5.9 \%$ & $8.3 \%$ & $9.0 \%$ & $9.0 \%$ & $8.6 \%$ & $8.7 \%$ & $8.1 \%$ & $8.4 \%$ \\
\hline $30-34$ & $6.4 \%$ & $6.1 \%$ & $5.1 \%$ & $8.7 \%$ & $9.1 \%$ & $9.8 \%$ & $10.7 \%$ & $12.5 \%$ & $12.4 \%$ & $14.3 \%$ & $15.2 \%$ & $15.6 \%$ & $15.0 \%$ & $12.6 \%$ \\
\hline 35-39 & $9.0 \%$ & $9.4 \%$ & $9.2 \%$ & $9.6 \%$ & $9.7 \%$ & $12.3 \%$ & $13.1 \%$ & $13.8 \%$ & $15.0 \%$ & $16.4 \%$ & $17.6 \%$ & $19.1 \%$ & $19.5 \%$ & $19.3 \%$ \\
\hline $40-44$ & $13.6 \%$ & $12.6 \%$ & $14.7 \%$ & $14.9 \%$ & $14.3 \%$ & $13.3 \%$ & $14.4 \%$ & $15.3 \%$ & $15.5 \%$ & $18.0 \%$ & $19.7 \%$ & $20.8 \%$ & $21.9 \%$ & $21.4 \%$ \\
\hline $45-49$ & $12.8 \%$ & $14.4 \%$ & $14.9 \%$ & $17.3 \%$ & $20.3 \%$ & $20.9 \%$ & $20.1 \%$ & $22.2 \%$ & $21.0 \%$ & $21.1 \%$ & $20.6 \%$ & $23.2 \%$ & $21.4 \%$ & $23.4 \%$ \\
\hline $50-54$ & $24.7 \%$ & $21.7 \%$ & $22.2 \%$ & $25.5 \%$ & $25.1 \%$ & $24.1 \%$ & $26.3 \%$ & $26.4 \%$ & $27.6 \%$ & $26.4 \%$ & $25.9 \%$ & $28.9 \%$ & $27.8 \%$ & $28.1 \%$ \\
\hline 55-59 & $30.3 \%$ & $25.4 \%$ & $28.5 \%$ & $28.5 \%$ & $29.4 \%$ & $31.1 \%$ & $31.1 \%$ & $30.7 \%$ & $32.4 \%$ & $31.3 \%$ & $35.5 \%$ & $33.2 \%$ & $30.2 \%$ & $28.8 \%$ \\
\hline $60-64$ & $33.3 \%$ & $38.4 \%$ & $39.2 \%$ & $39.7 \%$ & $37.5 \%$ & $30.9 \%$ & $34.4 \%$ & $37.5 \%$ & $35.8 \%$ & $36.0 \%$ & $37.2 \%$ & $39.3 \%$ & $35.2 \%$ & $35.3 \%$ \\
\hline $65+$ & $47.9 \%$ & $38.9 \%$ & $40.7 \%$ & $48.4 \%$ & $39.2 \%$ & $46.2 \%$ & $41.3 \%$ & $40.5 \%$ & $35.2 \%$ & $35.5 \%$ & $26.1 \%$ & $36.3 \%$ & $39.4 \%$ & $42.7 \%$ \\
\hline
\end{tabular}

Source: Authors' calculations based on the 1996 SIPP matched to the Detailed Earnings File 
Table A3. Probability of Contributing the Maximum by Sex, Earnings, and Year

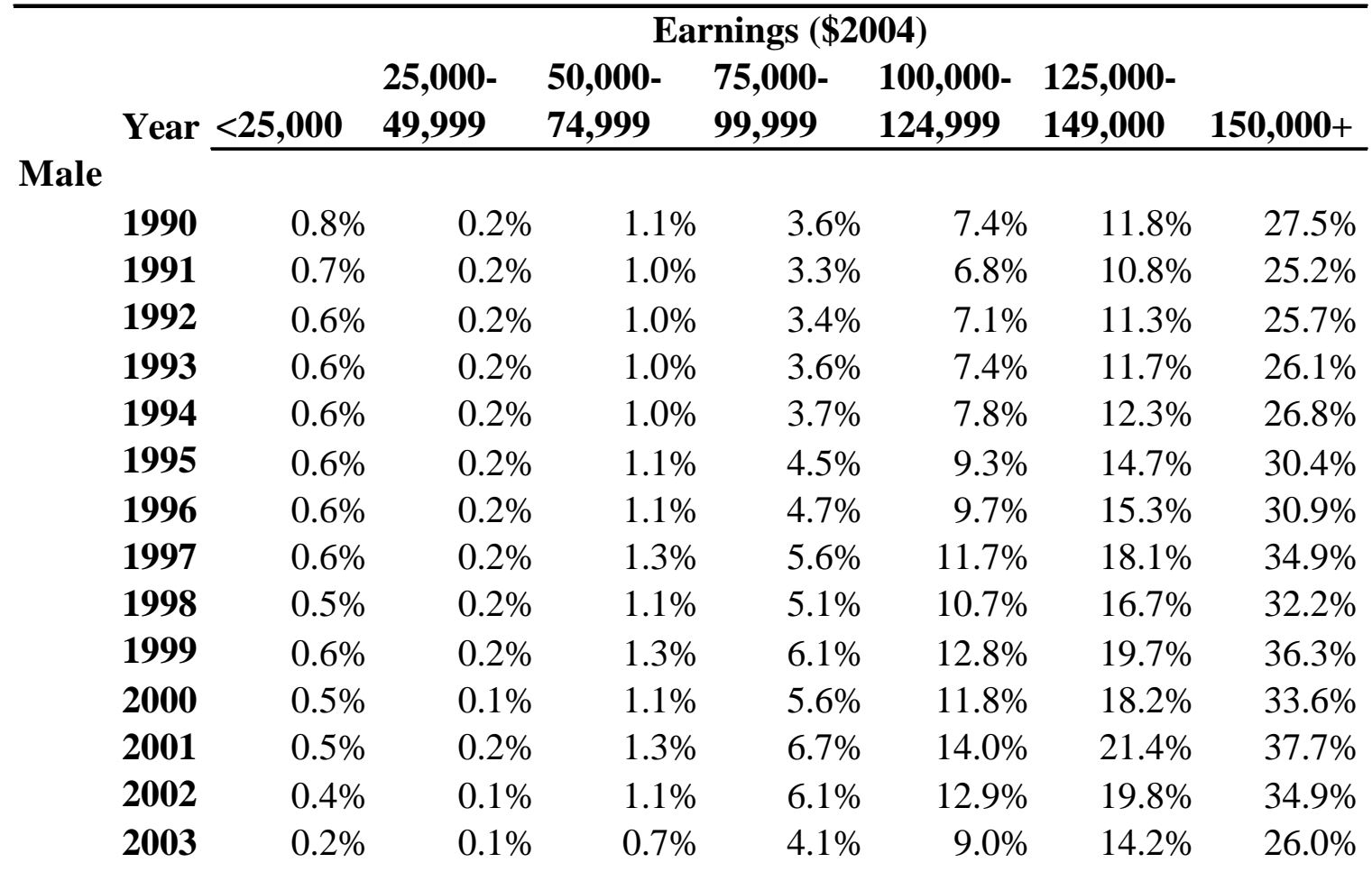

Female

\begin{tabular}{lrrrrrrr}
$\mathbf{1 9 9 0}$ & $0.7 \%$ & $0.6 \%$ & $1.8 \%$ & $5.6 \%$ & $10.7 \%$ & $19.7 \%$ & $36.8 \%$ \\
$\mathbf{1 9 9 1}$ & $0.6 \%$ & $0.5 \%$ & $1.5 \%$ & $5.1 \%$ & $9.8 \%$ & $18.2 \%$ & $34.1 \%$ \\
$\mathbf{1 9 9 2}$ & $0.6 \%$ & $0.5 \%$ & $1.5 \%$ & $5.3 \%$ & $10.3 \%$ & $19.0 \%$ & $34.7 \%$ \\
$\mathbf{1 9 9 3}$ & $0.5 \%$ & $0.5 \%$ & $1.5 \%$ & $5.5 \%$ & $10.7 \%$ & $19.6 \%$ & $35.2 \%$ \\
$\mathbf{1 9 9 4}$ & $0.5 \%$ & $0.4 \%$ & $1.5 \%$ & $5.8 \%$ & $11.2 \%$ & $20.5 \%$ & $35.9 \%$ \\
$\mathbf{1 9 9 5}$ & $0.5 \%$ & $0.5 \%$ & $1.8 \%$ & $6.9 \%$ & $13.4 \%$ & $24.0 \%$ & $40.2 \%$ \\
$\mathbf{1 9 9 6}$ & $0.5 \%$ & $0.5 \%$ & $1.8 \%$ & $7.2 \%$ & $14.0 \%$ & $24.9 \%$ & $40.7 \%$ \\
$\mathbf{1 9 9 7}$ & $0.6 \%$ & $0.5 \%$ & $2.1 \%$ & $8.6 \%$ & $16.6 \%$ & $28.8 \%$ & $45.2 \%$ \\
$\mathbf{1 9 9 8}$ & $0.4 \%$ & $0.4 \%$ & $1.8 \%$ & $7.8 \%$ & $15.3 \%$ & $26.9 \%$ & $42.2 \%$ \\
$\mathbf{1 9 9 9}$ & $0.5 \%$ & $0.5 \%$ & $2.1 \%$ & $9.4 \%$ & $18.1 \%$ & $31.0 \%$ & $46.6 \%$ \\
$\mathbf{2 0 0 0}$ & $0.4 \%$ & $0.4 \%$ & $1.8 \%$ & $8.5 \%$ & $16.7 \%$ & $29.0 \%$ & $43.7 \%$ \\
$\mathbf{2 0 0 1}$ & $0.4 \%$ & $0.4 \%$ & $2.1 \%$ & $10.2 \%$ & $19.7 \%$ & $33.3 \%$ & $48.1 \%$ \\
$\mathbf{2 0 0 2}$ & $0.4 \%$ & $0.3 \%$ & $1.8 \%$ & $9.2 \%$ & $18.2 \%$ & $31.2 \%$ & $45.1 \%$ \\
$\mathbf{2 0 0 3}$ & $0.2 \%$ & $0.2 \%$ & $1.2 \%$ & $6.4 \%$ & $13.0 \%$ & $23.3 \%$ & $35.0 \%$ \\
\hline
\end{tabular}

Source: Urban Institute model estimated from the 1996 SIPP linked to the DER.

Notes: Based on a 50-year-old, unmarried, white worker with no self employment income and no contribution history. 
Table A4. Probability of Contributing 10 Percent or the Maximum by Sex, Earnings, and Year

\begin{tabular}{|c|c|c|c|c|c|c|c|}
\hline \multirow[b]{3}{*}{ Male } & \multicolumn{7}{|c|}{ Earnings (\$2004) } \\
\hline & $<25,000$ & $\begin{array}{l}25,000- \\
49,999\end{array}$ & $\begin{array}{l}50,000- \\
74,999\end{array}$ & $\begin{array}{l}75,000- \\
99,999\end{array}$ & $\begin{array}{l}100,000- \\
124,999\end{array}$ & $\begin{array}{l}125,000- \\
149,000\end{array}$ & $150,000+$ \\
\hline & & & & & & & \\
\hline 1990 & $6.7 \%$ & $8.0 \%$ & $11.7 \%$ & $10.0 \%$ & $8.8 \%$ & $13.4 \%$ & $31.1 \%$ \\
\hline 1991 & $6.4 \%$ & $7.6 \%$ & $11.1 \%$ & $9.8 \%$ & $8.7 \%$ & $13.1 \%$ & $29.9 \%$ \\
\hline 1992 & $6.4 \%$ & $7.6 \%$ & $11.0 \%$ & $10.0 \%$ & $9.0 \%$ & $13.4 \%$ & $29.8 \%$ \\
\hline 1993 & $6.4 \%$ & $7.5 \%$ & $10.9 \%$ & $10.1 \%$ & $9.4 \%$ & $13.6 \%$ & $29.6 \%$ \\
\hline 1994 & $6.4 \%$ & $7.5 \%$ & $10.9 \%$ & $10.3 \%$ & $9.7 \%$ & $13.8 \%$ & $29.5 \%$ \\
\hline 1995 & $6.7 \%$ & $7.8 \%$ & $11.3 \%$ & $11.1 \%$ & $10.5 \%$ & $14.7 \%$ & $30.5 \%$ \\
\hline 1996 & $6.7 \%$ & $7.8 \%$ & $11.3 \%$ & $11.2 \%$ & $10.9 \%$ & $15.0 \%$ & $30.3 \%$ \\
\hline 1997 & $7.0 \%$ & $8.1 \%$ & $11.7 \%$ & $12.0 \%$ & $11.8 \%$ & $15.9 \%$ & $31.3 \%$ \\
\hline 1998 & $6.7 \%$ & $7.7 \%$ & $11.2 \%$ & $11.7 \%$ & $11.7 \%$ & $15.5 \%$ & $30.1 \%$ \\
\hline 1999 & $7.0 \%$ & $8.0 \%$ & $11.6 \%$ & $12.5 \%$ & $12.7 \%$ & $16.5 \%$ & $31.1 \%$ \\
\hline 2000 & $6.7 \%$ & $7.6 \%$ & $11.0 \%$ & $12.1 \%$ & $12.5 \%$ & $16.1 \%$ & $29.9 \%$ \\
\hline 2001 & $7.1 \%$ & $8.0 \%$ & $11.5 \%$ & $12.9 \%$ & $13.6 \%$ & $17.1 \%$ & $30.9 \%$ \\
\hline 2002 & $6.7 \%$ & $7.6 \%$ & $10.9 \%$ & $12.6 \%$ & $13.4 \%$ & $16.7 \%$ & $29.7 \%$ \\
\hline 2003 & $5.8 \%$ & $6.5 \%$ & $9.5 \%$ & $11.2 \%$ & $12.1 \%$ & $14.9 \%$ & $26.4 \%$ \\
\hline
\end{tabular}

Female

\begin{tabular}{llllllll}
$\mathbf{1 9 9 0}$ & $9.1 \%$ & $9.7 \%$ & $14.7 \%$ & $14.5 \%$ & $12.9 \%$ & $24.1 \%$ & $44.5 \%$ \\
$\mathbf{1 9 9 1}$ & $8.7 \%$ & $9.3 \%$ & $14.0 \%$ & $14.2 \%$ & $12.8 \%$ & $23.6 \%$ & $43.1 \%$ \\
$\mathbf{1 9 9 2}$ & $8.7 \%$ & $9.2 \%$ & $13.9 \%$ & $14.4 \%$ & $13.2 \%$ & $24.0 \%$ & $43.0 \%$ \\
$\mathbf{1 9 9 3}$ & $8.6 \%$ & $9.1 \%$ & $13.8 \%$ & $14.7 \%$ & $13.6 \%$ & $24.3 \%$ & $42.8 \%$ \\
$\mathbf{1 9 9 4}$ & $8.7 \%$ & $9.1 \%$ & $13.8 \%$ & $15.0 \%$ & $14.1 \%$ & $24.8 \%$ & $42.7 \%$ \\
$\mathbf{1 9 9 5}$ & $9.1 \%$ & $9.5 \%$ & $14.3 \%$ & $15.9 \%$ & $15.2 \%$ & $26.1 \%$ & $43.8 \%$ \\
$\mathbf{1 9 9 6}$ & $9.1 \%$ & $9.5 \%$ & $14.2 \%$ & $16.2 \%$ & $15.7 \%$ & $26.5 \%$ & $43.6 \%$ \\
$\mathbf{1 9 9 7}$ & $9.5 \%$ & $9.9 \%$ & $14.8 \%$ & $17.2 \%$ & $17.0 \%$ & $28.0 \%$ & $44.8 \%$ \\
$\mathbf{1 9 9 8}$ & $9.1 \%$ & $9.4 \%$ & $14.1 \%$ & $16.8 \%$ & $16.8 \%$ & $27.4 \%$ & $43.4 \%$ \\
$\mathbf{1 9 9 9}$ & $9.5 \%$ & $9.8 \%$ & $14.7 \%$ & $17.8 \%$ & $18.1 \%$ & $28.9 \%$ & $44.5 \%$ \\
$\mathbf{2 0 0 0}$ & $9.1 \%$ & $9.3 \%$ & $14.0 \%$ & $17.4 \%$ & $17.9 \%$ & $28.3 \%$ & $43.1 \%$ \\
$\mathbf{2 0 0 1}$ & $9.6 \%$ & $9.7 \%$ & $14.5 \%$ & $18.5 \%$ & $19.3 \%$ & $29.8 \%$ & $44.3 \%$ \\
$\mathbf{2 0 0 2}$ & $9.1 \%$ & $9.2 \%$ & $13.8 \%$ & $18.0 \%$ & $19.1 \%$ & $29.1 \%$ & $42.9 \%$ \\
$\mathbf{2 0 0 3}$ & $7.9 \%$ & $8.0 \%$ & $12.0 \%$ & $16.1 \%$ & $17.4 \%$ & $26.5 \%$ & $39.0 \%$ \\
\hline
\end{tabular}

Source: Urban Institute model estimated from the 1996 SIPP linked to the DER.

Notes: Based on a 50-year-old, unmarried, white worker with no self employment income and no contribution history. 


\section{$\underline{\text { RECENT WORKING PAPERS FROM THE }}$ \\ CENTER FOR RETIREMENT RESEARCH AT BOSTON COLLEGE}

When the Nest Egg Cracks: Financial Consequences of Health Problems, Marital Status Changes, and Job Layoffs at Older Ages.

Richard W. Johnson, Gordon B.T. Mermin and Cori E. Uccello, December 2005

How Portfolios Evolve after Retirement: the Effect of Health Shocks.

Courtney Coile and Kevin Milligan, December 2005

Demographic Interactions between North and South and the Implications for North-South Capital Flows

Ralph C. Bryant, December 2005

The Decline in Household Savings: What can we learn from Survey Data?

Barry Bosworth and Lisa Bell, December 2005

The Retirement Consumption Conundrum: Evidence from a Consumption Survey Jonathan Fisher, David S. Johnson, Joseph Marchand, Timothy M. Smeeding, and Barbara Boyle Torrey, December 2005

Life is Cheap:Using Mortality Bonds to Hedge Aggregate Mortality Risk Leora Friedberg and Anthony Webb, October, 2005

How Much Is the Working -Age Population Saving?

Alicia H. Munnell, Francesca Golub-Sass, and Andrew Varani, October 2005

Top Ten Myths of Social Security Reform

Jeffrey R. Brown, Kevin Hassett, and Kent Smetters, October 2005

What Replacement Rates Do Households Actually Experience in Retirement?

Alicia H. Munnell and Mauricio Soto, August 2005

Bequests, Inheritances and Family Traditions

Donald Cox and Oded Stark, August 2005

Local Labor Market Conditions and Retirement Behavior

Dan A. Black and Xiaoli Liang, May 2005

All working papers are available on the Center for Retirement Research website (http://www.bc.edu/crr) and can be requested by e-mail (crr@bc.edu) or phone (617-552-1762). 